unesp UNIVERSIDADE ESTADUAL PAULISTA

"JÚLIO DE MESQUITA FILHO"

Faculdade de Ciências e Letras

Campus de Araraquara - SP

ALINE TAÍS CARA

\title{
A RELAÇÃO IRONIA/ORALIDADE EM L'IMITATION DE NOTRE-DAME LA LUNE, DE JULES LAFORGUE
}


ALINE TAÍS CARA

\section{A RELAÇÃO IRONIA/ORALIDADE EM L'IMITATION DE NOTRE-DAME LA LUNE, DE JULES LAFORGUE}

Dissertação de Mestrado, apresentada ao Programa de Pós-Graduação em Estudos Literários da Faculdade de Ciências e Letras/ Unesp Araraquara, como requisito para a obtenção do título de Mestre.

Orientadora: $\operatorname{Prof}^{\mathrm{a}}$. Dr ${ }^{\mathrm{a}}$.Guacira Marcondes Machado Leite 


\section{A RELAÇÃO IRONIA/ORALIDADE EM L'IMITATION DE NOTRE-DAME LA $L U N E$, DE JULES LAFORGUE}

Dissertação de Mestrado, apresentada ao Programa de Pós-Graduação em Estudos Literários da Faculdade de Ciências e Letras/ Unesp Araraquara, como requisito para a obtenção do título de Mestre.

Orientadora: $\operatorname{Prof}^{\mathrm{a}}$. Dr ${ }^{\mathrm{a}}$.Guacira Marcondes Machado Leite

MEMBROS COMPONENTES DA BANCA EXAMINADORA:

Presidente e Orientador: $\operatorname{Prof}^{\mathrm{a}} \operatorname{Dr}^{\mathrm{a}}$ Guacira Marcondes Machado Leite (UNESP - FCLAr)

Membro Titular: Prof $^{a}$ Dr $^{a}$ Glória Carneiro do Amaral (USP - FFLCH)

Membro Titular: $\operatorname{Prof}^{a} \operatorname{Dr}^{a}$ Andressa Cristina de Oliveira (UNESP - FCLAr)

Local: Universidade Estadual Paulista

Faculdade de Ciências e Letras

UNESP - Campus de Araraquara 
À Professora Guacira Marcondes Machado Leite, fonte de ensinamentos, de inspiração, de incentivo e de muito carinho; que acreditou em mim e instigou-me a buscar conhecimento e novos horizontes. 


\section{AGRADECIMENTOS}

Este trabalho foi possível graças à existência de pessoas especiais em minha vida, sem as quais talvez não tivesse força e inspiração suficientes para concluir a redação destas páginas. Meus sinceros agradecimentos a todas elas.

À professora Guacira Marcondes Machado Leite, primeiramente por acreditar em meu trabalho e em minha capacidade de realizar esta viagem pela literatura. Obrigada pela atenção, pelos conselhos tão preciosos, pela dedicação e pela orientação extraordinária, não apenas para a escrita desta dissertação, mas também para toda a minha vida. As palavras que ouvi ficarão guardadas com carinho em minha lembrança e em meu coração, como direcionamento e presente por ter com ela convivido.

À minha família, refúgio e suporte nos momentos mais difíceis, desde a entrada na universidade. Foi uma luta permanecer em Araraquara e concluir os estudos, bem como ingressar no Mestrado. Contudo, meus pais e meu irmão, sobretudo, estiveram sempre ao meu lado, apoiando minhas decisões e alicerçando minhas escolhas. Os obstáculos vencidos devem-se, em grande parte, à força retirada dessas pessoas tão importantes.

Ao meu marido, amigo e companheiro de todos os momentos, felizes e sofridos, que acompanhou meus passos desde o início dessa caminhada, primeiro como amigo, depois como namorado e, hoje, como esposo. O Daniel é um ser humano maravilhoso, compreensivo e meu maior fã. Sempre torceu e torce muito por mim e pelas minhas realizações profissionais, incentivando meus estudos e dedicando todo o seu amor em cada dia de convivência. A presença dele foi e é fundamental para a composição destas linhas e das que poderão ainda ser escritas. Não posso me esquecer de citar a família de meu esposo, meu sogro, minha sogra e meus cunhados, pois sempre fizeram com que eu me sentisse parte 
integrante da família, além de rezarem muito para que este trabalho fosse concluído com sucesso. Agradeço o carinho e o amor com que me tratam.

Aos meus amigos, grandes incentivadores deste trabalho, obrigada pelo carinho e pela valiosa amizade. Primeiramente, agradeço às meninas que moraram comigo em Araraquara e que, durante alguns anos, foram a minha família: Alessandra, minha verdadeira irmã desde o início da graduação, a pessoa mais incrível e especial que já conheci e que só poderia encontrar um esposo tão maravilhoso quanto ela. Paula, irreverente e divertida, cujos horizontes são tão amplos que o céu é o limite. Paola, inteligente e brilhante, cujo nome ainda será visto nas mais importantes páginas, pois seus anseios são infinitos. Priscila, que não morou efetivamente comigo, mas conviveu tanto com minhas dúvidas, indecisões e interesses que se fez presente em todos os momentos inesquecíveis. Paulo, o primeiro amigo que fiz em terras araraquarenses, responsável por eu abrir minha imaginação e sonhar com um mundo construído por ela, habitando as estrelas mais distantes e luzentes.

Há, também, duas grandes amigas baririenses que não posso deixar de citar: Mariana, companheira de berço, cuja família é como se fosse minha. Esta pequena detém todo o meu amor e admiração, pois é especial e sempre esteve ao meu lado com seu apoio e carinho. Meire, querida professora e, hoje, colega de trabalho, espelho para minhas atitudes e dizeres, incentivadora do meu gosto pelas letras, amiga e conselheira.

À literatura, pela possibilidade de viagens pelas palavras, inspiradas pelo puro prazer de estar em meio a elas.

Aos professores que passaram pela minha graduação, pós-graduação e bancas, pelos ensinamentos e pelas sugestões pertinentes. 
$C^{\prime}$ est le temps que tu as perdu pour ta rose qui fait ta rose si importante. (SAINT-EXUPÉRY, 1999, p. 78) 


\section{RESUMO}

Jules Laforgue (1860-1887) foi um grande decadentista/simbolista francês; as características de suas obras tocam esses dois importantes movimentos literários. O Decadentismo foi anterior ao Simbolismo, com teor mais negativista e pessimista; o Simbolismo foi composto de duas vertentes: a "sério-estética", mais conhecida e estudada, e a "coloquial- irônica". A partir desta, menos abordada do que aquela, desenvolvem-se os recursos utilizados nas composições de Laforgue, apesar de o escritor ultrapassar os limites de movimentos e tendências literárias, produzindo algo novo e original. Escreveu obras poéticas e em prosa, as quais revelam características bastante particulares. Com relação à poética, a crítica atual tem reconhecido a importância do poeta para a poesia subsequente a ele, inclusive a dos modernistas brasileiros como Carlos Drummond de Andrade e Manuel Bandeira. Laforgue foi, de certa forma, sufocado pelos seus contemporâneos Baudelaire, Verlaine, Mallarmé e Rimbaud; todavia está inserido entre os grandes nomes da modernidade poética, devido à sua importância literária. Seus escritos surpreendentes e suas características inovadoras é que fazem dele o inspirador e mestre de personalidades como Ezra Pound e T. S. Eliot. Podem-se perceber algumas constantes na obra de Laforgue: ironia, paródia, a procura por formas orais, a criação de novas palavras e o humor. É fato dizer que sua obra é rica em recursos estilísticos e em vocabulário; há forte presença intertextual de mitos, lendas, cantigas, citações de outros textos, de autores e de personagens conhecidos, o que torna as composições do poeta ainda mais complexas. $\mathrm{O}$ escritor cria, com maestria, uma linguagem própria e, através de seus neologismos, da dissonância e da quebra de expectativa, impressiona os leitores e demonstra sua relevância literária. Analisando poemas do livro L'Imitation de Notre-Dame La Lune, escolhido para ser a base das considerações tecidas por este trabalho, percebemos, muitas vezes, o intuito de realizar uma poesia diferente, 
preocupada em jogar com as palavras e com as expressões, sem necessariamente apresentar associações no campo semântico. Laforgue, ao praticar a bufonaria verbal, juntamente com os diversos recursos que utiliza, surpreende seu leitor e cria uma nova forma de versejar, produzindo poemas complexos e ricos em possibilidades de interpretação, demonstrando um fazer poético original.

Palavras-chave: Ironia. Oralidade. Poesia. Originalidade. Crítica. Dissonância. 


\section{RÉSUMÉ}

Jules Laforgue (1860-1887) a été um grand décadentiste/symboliste français; les caractéristiques de ses oeuvres touchent ces deux importants mouvements littéraires. Le Décadentisme a été antérieur au Symbolisme, avec um trait plus négativiste et pessimiste; le Symbolisme a été composé de deux tendances: la "sérieux-esthétique", plus connue et étudiée, et la "prosaïque-ironique". À partir de celle-ci, moins étudiée que celle-là, les recours utilisés sont développés dans les compositions de Laforgue, même si l'écrivain dépasse les limites des mouvements littéraires, en écrivant des textes différents et originaux. Il a produit des oeuvres poétiques et en prose, qui révèlent des caractéristiques très particulières. Par rapport à la poétique, la critique actuelle a reconnu l'importance du poète pour la poésie postérieure à lui, inclusivement celle des modernistes brésiliens comme Carlos Dummond de Andrade et Manuel Bandeira. Laforgue a été, de certe façon, suffoqué par ses contemporains Baudelaire, Verlaine, Mallarmé et Rimbaud; mais il est inséré entre les grands noms de la modernité poétique, dû à son importance littéraire. Ses écrits surprenants et ses caractéristiques innovatrices font de lui l'inspirateur et maître de personnalités comme Ezra Pound et T. S. Eliot. Il est possible de percevoir quelques constantes dans l'oeuvre de Laforgue: ironie, parodie, la quête pour des formes orales, la création de mots nouveaux et l'humour. Il est vrai de dire que son oeuvre est riche en recours stylistiques et en vocabulaire; il y a une forte présence intertextuel des mythes, des légendes, des chansons, de citations de textes d'autres auteurs et de personnages connus, ce qui rend les compositions du poète encore plus complexes. L'écrivain crée avec maîtrise un langage propre et, à travers ses néologismes, la dissonance et la rupture des attentes, il impressionne les lecteurs et montre son importance littéraire. En analysant les poèmes du livre L'Imitation de Notre-Dame la Lune, choisi pour être la base des considérations tissues par ce travail, nous avons aperçu, 
plusieurs fois, l'intention de réaliser une poésie différente, préocupée de jouer avec les mots et avec les expressions, sans nécessairement présenter des combinaisons sur le champs sémantique. Quand Laforgue réalise sa buffonnerie verbal, avec les divers recours qu'il emploi, il surprend son lecteur et crée une nouvelle forme de faire des vers, aboutissant à des poèmes complexes et riches en possibilités d'interprétation, montrant un travail poétique original.

Mots-clé: Ironie. Oralité. Poésie. Originalité. Critique. Dissonance. 
SUMÁRIO

1 INTRODUÇÃO.......................................................................................................13

2 DECADENTISMO, SIMBOLISMO E JULES LAFORGUE: CARACTERÍSTICAS E INFLUÊNCIAS..................................................................15

3 JULES LAFORGUE: VIDA E OBRA.................................................................29

4 RECURSOS UTILIZADOS..........................................................................................33

4. 1 IRONIA: COMPLEXIDADE POÉTICA............................................................33

4. 2 ORALIDADE...........................................................................................................39

4. 3 O MITO E SUA RELAÇÃO COM A IRONIA.................................................47

4. 4 RECURSOS GRÁFICOS, ESTILÍSTICOS E LEXICAIS.................................56

4.5 FORMAS DA LÍNGUA E SINGULARIDADES DA ESCRITA...................62

5 L'IMITATION DE NOTRE-DAME LA LUNE: ALGUMAS ANÁLISES.......64

6 LAFORGUE E O PIERRÔ LUNAR....................................................................83

7 CONSIDERAÇÕES FINAIS....................................................................................98

8 BIBLIOGRAFIA...........................................................................................................102

9 ANEXOS........................................................................................................................108 


\section{Introdução}

Em 2005, começamos a desenvolver um trabalho de análise de poemas de autores inseridos no Simbolismo brasileiro. Em decorrência desses estudos, o gosto pelo movimento cresceu, mas a busca era outra: encontrar um autor que, mesmo fazendo parte do movimento, fosse tão crítico e irônico a ponto de transpô-lo. Assim, surgiu o interesse pelo poeta francês Jules Laforgue (1860-1887); passamos, pois, em 2007, a dedicar-nos ao estudo de sua produção, sobretudo a poética. Jules Laforgue foi um importante decadentista/simbolista cuja obra perpassa estes dois movimentos literários; seguiu, segundo denominação de Wilson (1967), a corrente "coloquial-irônica" do simbolismo, fazendo uso, portanto, de recursos como ironia, crítica, humor e dissonância. O escritor nasceu em Montevidéu, Uruguai, de pais franceses, e aos seis anos de idade mudou-se para a França. Por isso, escreveu em francês e também realizou traduções de autores estrangeiros para o idioma adotado; dentre estes, Walt Whitman.

Sua obra poética é composta por Le Sanglot de la Terre, Les Complaintes, L'Imitation de Notre-Dame la Lune, Des Fleurs de bonne volonté e Derniers Vers. Após algumas leituras, percebemos grande semelhança entre os poemas lunares e os que falam sobre o Pierrô; por conseguinte, ficaremos retidos, principalmente, no título L'Imitation de NotreDame la Lune, em virtude de que este contém ambas as temáticas escolhidas para compor esta dissertação.

No entanto, eventualmente serão utilizados poemas também do livro Les Complaintes, por serem estes repletos de oralidade, e de Des Fleurs de bonne volonté, em decorrência das inúmeras referências míticas que podem ser encontradas no livro. Em toda a obra poética de Laforgue, o leitor pode visualisar o emprego de novos e originais recursos estilísticos e lexicais, característica do fazer poético do escritor, sendo a ironia e a oralidade, os mais marcantes. 
Contudo, faz-se antes necessário discorrer sobre como o autor se insere nos movimentos dos quais faz parte. Isso porque Laforgue não foi um poeta preso a estéticas, seguidor de todos os postulados. Assim, vamos tratar inicialmente do Simbolismo e do Decadentismo, apresentando suas características e, em seguida, como estas aparecem na obra do poeta. Além disso, serão conceituados os recursos utilizados pelo escritor, não para meramente apresentá-los, mas para explicá-los do ponto de vista de sua obra, que tem características próprias dentro daqueles dois movimentos, antes de, finalmente, ser abordado o corpus já anunciado, por meio da análise de seus poemas.

Será feita uma passagem pela vida do escritor francês, partindo do princípio de que ele é, ainda, pouco conhecido e estudado, visando a informar melhor os leitores destas páginas. Soma-se a isso o fato de que muitos momentos da vida do poeta, os quais citaremos, interferiram consideravelmente na composição de sua obra. 


\section{Decadentismo, Simbolismo e Jules Laforgue: características e influências}

A crítica, desde meados do século $\mathrm{XX}$, tem reconhecido a importância de Jules Laforgue para a poesia subsequente a ele, visto que o poeta está à frente de seu tempo, no que diz respeito a características e recursos que utiliza. Ele foi, de certa forma, eclipsado pelos seus contemporâneos tão conhecidos: Baudelaire, Mallarmé, Rimbaud e Verlaine; todavia pode e deve ser inserido entre os grandes nomes dessa época literária, ou seja, da modernidade poética, pois sua obra tem características que perpassam o Decadentismo e o Simbolismo. Os escritos surpreendentes e as características inovadoras é que fazem dele o inspirador e mestre de poetas como Ezra Pound e T. S. Eliot.

Existem teóricos que enxergam aqueles movimentos como distintos; há os que admitem haver uma linha tênue entre a essência decadentista e a simbolista; outros, ainda, consideram o Decadentismo e o Simbolismo duas denominações para uma mesma tendência. Apesar de os simbolistas terem sido inicialmente chamados de decadentes pela proximidade existente entre os movimentos, vamos considerá-los mostrando, além das semelhanças, as diferenças existentes entre essas duas correntes, e como o autor Jules Laforgue pode ser inserido, via de regra, em ambas.

Segundo Gustave Kahn, havia decadentes e simbolistas em 1885, contudo os primeiros existiam em maior número (apud Moretto, 1989, p. 163):

Em 1885, havia decadentes e simbolistas, muitos decadentes e poucos simbolistas. A palavra decadente fora pronunciada a palavra simbolista ainda não; falávamos em símbolo, não criáramos a palavra genérica simbolismo e os decadentes e os simbolistas eram então coisas completamente diferentes. A palavra decadente fora criada por jornalistas, alguns a haviam, diziam eles, ajuntado como os goeux da Holanda haviam abordado o epíteto injurioso; nem tão injurioso nem tão inexato. 
Anna Balakian (2000) refere-se a esta fala de Kahn em seu O Simbolismo, p. 80:

Quando Gustave Kahn sugeriu em seu Symbolistes et Décadents que em 1885 existiam mais "decadentes" do que simbolistas, estava querendo dizer que o verdadeiro simbolista era o técnico, enquanto o "decadente" era o diletante que apenas respirava a atmosfera espiritual da melancolia e do ennui.

Também Ernest Raynaud discorre sobre as diferenças entre decadentes e simbolistas (apud Moretto 1989, p. 187):

Os Decadentes diferiam dos Simbolistas enquanto admitiam a emoção direta, a tradução exata dos fenômenos da vida, em lugar de exigir sua transposição, enquanto não alongavam excessivamente $\mathrm{o}$ alexandrino $\mathrm{e}$ usavam poemas de forma fixa. Punham também uma menor gravidade estudada em seus manifestos e não se preocupavam em dar-lhes um cunho científico, um sabor de axioma, o picante de uma fórmula algébrica.

E acrescenta (p.188-189):

Contudo, a ação dos Simbolistas e dos Decadentes contra a literatura em voga era paralela. Tinham os mesmos ódios e as mesmas admirações. Tinham o mesmo desejo de introduzir em seus versos maior mistério, mais sonho, mais música e substituir, ao modo narrativo e didático, um método sintético violentamente conciso. Uns e outros sentiam a necessidade de se libertarem de fórmulas caducas e de reformarem a prosódia, porém, os Decadentes não queriam fazer tábua rasa do Passado. Preconizavam reformas indispensáveis, conduzidas com método e prudência. Os Simbolistas, ao contrário, nada queriam conservar de nossos velhos usos e ambicionavam criar, como um só bloco, um novo modo de expressão.

Segundo Scepi (2000), o fim do século XIX é comumente apresentado como um período de intensa turbulência poética, rico de provocações e de transgressões. Certamente, as condições sociopolíticas favoreceram o aparecimento de uma estética da ruptura, denunciando a insuficiência do Parnaso e do Naturalismo. Surgirão, em meio às ruínas dessa época, as visões das "inteligências escolhidas" e das "almas elevadas", aferindo ao poeta o título de vidente, eleito ou demiurgo. A decadência carregaria a bandeira do desencorajamento intelectual de uma juventude derrotada. 
Faz-se necessário, neste momento, discorrermos a respeito da modernidade literária. A concepção de seu início provoca divergências entre os teóricos; contudo, talvez a maioria siga a tendência de definir sua gênese no século XVIII, devido às inúmeras mudanças e inovações que ocorreram nessa época, aos projetos de reforma social a à criação de utopias, somados à revolução científica e à filosófica. Segundo Paz (1993), a modernidade começa com contestações à religião, à filosofia, à moral, ao direito, à história, à economia e à política, apresentando a crítica como seu traço marcante e diferencial, já que os conceitos caros à Idade Moderna nasceram da crítica: evolução, progresso, liberdade, ciência, técnica e democracia.

O Romantismo é a grande negação dessa modernidade concebida até então. Ele recria essa noção trazendo a visão das correspondências, as quais serão apresentadas por Baudelaire. A ironia é um recurso presente, juntamente com a dissonância, os quais serão trabalhados minuciosamente nas obras de Jules Laforgue, de forma autêntica e inovadora.

O século XIX reflete o apogeu dessa modernidade, com o Romantismo e com o Simbolismo, preparando o terreno para os movimentos de vanguarda. Nessa época, acontece a crise da representação, uma crise ética e, sobretudo, estética, provocando a tentativa de produzir o novo a qualquer preço, decorrente da destruição dos referenciais que vinham norteando o pensamento. A partir desse momento, a busca pelo original leva os artistas a ensaiarem combinações inusitadas, valendo-se da completa falta de padrões.

É nesse âmbito que surge o primeiro dever do artista moderno, o de emancipar-se, fugir dos cânones literários, do academismo e dos nomes do passado. Laforgue irá além disso: utilizará as características acima citadas com a finalidade de realizar e validar a ironia, que é a base de sua obra e também do Simbolismo, segundo Bradburry e McFarlane (1989, p. 166), quando dizem que "o simbolismo traz em si a passagem de uma estética romântica para uma estética modernamente irônica". O poeta vai tentar ser original a qualquer preço, inserindo-se na perspectiva moderna de ruptura e, para tanto, cria uma linguagem própria, distinta, 
refinada, minuciosa e clownesca. Seus poemas refletirão uma melancolia incessante, ligada ao dia-a-dia, ao cotidiano, à nostalgia incurável da vida, como o spleen baudelairiano, mas sem deixar de lado o humor.

O Decadentismo é um pouco anterior ao Simbolismo, porém com teor mais pessimista, negativista. Como diz Peyre (1983), nos últimos decênios do século XIX, a literatura simbolista prezou todo o cansaço de viver, o langor, o isolamento em relação à sociedade tecnológica, considerada materialista. Isso faz com que muitos observadores e historiadores denominem os escritos que contêm tais características como "decadentistas", ou seja, elaborados pelos "decadentes", termo existente para denominar os escritores adeptos do pessimismo e da decadência iminente. Tentava-se convencer o mundo literário de que nada mais restava à sociedade corroída pela decadência, pelo esgotamento; as únicas alternativas eram desmoroná-la ou rejuvenescê-la por meio da religião, do ocultismo ou da barbárie. Essa decadência, ou melhor, a noção de decadente tem origens muito antigas, desde a queda - a decadência - do Império Romano (por volta de 476 d. C.), ou antes, ainda, com Platão. Este não utilizava o termo decadente, mas defendia a superioridade do homem antigo, pois, para ele, os que viriam encontrariam teorias já formadas, ou, ao menos, iniciadas. Sua crença em um mundo das ideias também implica a concepção de decadência, visto que, segundo ele, o lugar onde vivemos é apenas uma sombra de um lugar ideal e perfeito.

O homem decadente é aquele que surge, segundo Gomes (1994), dentro de uma grave crise social do final do século XIX. A Revolução Industrial que acontecia nessa época favorecia situações como o inchamento das cidades, a obsessão com a moda, a dúvida quanto aos métodos científicos, a impressão de que a sociedade estava se tornando cada vez mais materialista, aguçando a crise latente e provocando o sentimento negativista. O pessimismo da época cultiva o "decadente", aquele que volta as costas à sociedade, ao mundo grosseiro e hostil, aquele que se isola em sua torre de marfim e que busca sensações mais refinadas. 
Citando Moretto (1989), há, nesse momento, uma contradição: a geração de 1880 sente um frio de decadência e de morte, mas busca algo diferente, a renovação dos conceitos. Instaura-se uma luta contra as escolas parnasiana e naturalista, contra o academismo poético. E, assim, o Decadentismo segue a linha do idealismo. Esta tendência nasce na França com Huysmans e seu À Rebours, praticamente um manual dessa estética, podendo ser considerado uma bíblia decadentista. O autor consegue captar a alma decadente, sondar os abismos do ser, descrever um espírito complexo e refinado através de uma linguagem minuciosa e elaborada. O protagonista, des Esseintes, sentia profunda irritação pelo classicismo e atração pela extravagância, pelo requinte e pelo exótico. Interessava-se demasiadamente pelo barroco, pelo artificial, pelas quintessências do latim, pelos anagramas, epigramas e acrósticos latinos. Excêntrico e abastado, des Esseintes era tomado por um enorme tédio, gerado pela abundância, reflexo da filosofia de Schopenhauer. Buscando fugir desse tédio, refinará cada vez mais os seus prazeres, ousando e explorando a sinestesia, dedicando-se aos detalhes do olfato e a aventuras eróticas, movidas pelo instinto. Somado ao encanto por escritores latinos, destaca alguns modernos de sua preferência: Mallarmé, Verlaine, Villiers de l'Isle-Adam, Baudelaire e Tristan Corbière. E Huysmans, em um prefácio escrito quase vinte anos após o romance, cita Jules Laforgue (1987, p. 265):

Corbière, Mallarmé, Verlaine. Nada tenho a cortar do que escrevi há dezenove anos; mantive a minha admiração por esses escritores; a que eu professava por Verlaine aumentou inclusive. Arthur Rimbaud e Jules Laforgue teriam merecido figurar no florilégio de des Esseintes, mas não havia ainda nada impresso naquela época e só bem mais tarde foi que suas obras apareceram.

Os adeptos do Decadentismo adotavam, portanto, um vocabulário rebuscado; estetizavam a vida, mostravam horror ao natural, declarado no gosto refinado do estético e do artificial; não queriam comunhão com o povo, já que, para eles, a arte era destinada a eleitos e iniciados. O personagem de Huysmans torna-se símbolo do homem decadente, por seu gosto 
pelo aberrante, pelo perverso, pelo diferente, por sua visão moderna de uma arte refinada e pela reclusão: afasta-se da convivência humana para viver seus desejos e caprichos não compreendidos, traço comum entre os decadentistas e simbolistas, ilustrado por várias passagens de Às Avessas, como a da compra de uma tartaruga que seria cravejada de ouro e pedrarias, da aquisição dos tapetes raros, da longa viagem realizada apenas com a ida a um restaurante local e do apreço pelas plantas aberrantes, como as carnívoras, ou as artificiais: "Depois das flores artificiais a imitar as verdadeiras, queria flores naturais que imitassem as falsas". (Huysmans, 1987, p. 121). Estas linhas apresentam, claramente, a excentricidade, a busca pelo exótico e pelo diferente, além do eterno descontentamento do personagem des Esseintes, isolado em sua residência por odiar e rejeitar a sociedade.

Muitos não lutavam para conquistar o espaço que almejavam e acreditavam merecer na sociedade; se não encontravam nela o seu lugar, isolavam-se a fim de expressar-se sem reprovas e de manifestar sua crítica. Laforgue, ao contrário, é um dos que, para criticar aquilo que não aceita, permanece em meio às pessoas, mesmo odiando a sociedade, e recria a poesia ao invés de se isolar em convenções poéticas.

Segundo Moretto (1989), em abril de 1886, Anatole Baju fundou o jornal Le Décadent Littéraire et Artistique e publicou o manifesto Aux Lecteurs. Telles (1992) afirma que o movimento decadentista terminaria três anos depois, confundindo-se com o Simbolismo. Este se opõe ao Parnasianismo buscando renovação, apesar de muitos simbolistas terem nascido em meio aos parnasianos, de acordo com Martino (1925). O movimento foi um vento de liberdade, rompendo com a tradição vigente; teve a música como grande influência e aliada, sendo Wilhelm Richard Wagner, compositor alemão, o nome de maior relevância, por sua ideia de arte total e pela descoberta de novas combinações de comunicação artística. A influência de Wagner foi tão importante quanto a de qualquer poeta, pois a música tem papel significativo no movimento, devido ao desejo dos simbolistas de elevarem a poesia à 
condição de música, a mais subjetiva das artes. O subjetivismo é um traço marcante na poesia simbolista, além da indefinição que, desde Poe, revela a verdadeira expressão musical. Para os escritores, fazia-se necessário o encontro com o "eu" mais profundo, um "eu" diferente do romântico na medida em que não era envolto por sentimentalismos e suspiros, era o "eu" mais interior e mais secreto que podia existir. Wilson (1967) lembra que, algumas vezes, os simbolistas fizeram da poesia algo tão privativo do poeta, que ela se tornou incomunicável ao leitor, fato que foi notado e ironizado por Jules Laforgue.

O Simbolismo tem suas raízes no Romantismo, mas não é meramente um prolongamento deste, é uma contraparte, uma outra face dele. Também os românticos tiveram considerável influência sobre o movimento, sobretudo Edgar Allan Poe, bastante apreciado por Baudelaire.

O movimento simbolista vingou na França entre 1885 e 1895, período em que se formou um cénacle que publicou manifestos, revistas literárias como La Vogue, Revue Indépendante, La Revue Wagnerienne e La Décadence, e atraiu para Paris poetas e literatos de todo o Ocidente. Os escritores franceses de grande renome do século XIX, Nerval, Baudelaire, Verlaine, Rimbaud e Mallarmé podem ser considerados antecipadores do movimento, pois já apresentavam, em seus escritos, antes mesmo que o Simbolismo eclodisse, características que seriam caras a esta geração. Les Fleurs du Mal (1857), de Baudelaire, provocou grande escândalo, pois rompeu com temas considerados tabus e buscou criar uma nova poesia. Entre os inúmeros poetas da época, Jules Laforgue aparece como o nome significativo que foi retomado no século XX pelas características particulares de sua obra, a qual ficou tanto tempo ofuscada aos olhos da crítica.

Laforgue discorre sobre o fato de Baudelaire produzir versos que se desenvolvem com indiferença, fórmula que aquele desenvolverá e inserirá em sua poética. Além disso, a poesia rompe, em ambos os escritores, com o público, sendo acessível apenas a iniciados. 
O simbolismo espalhou-se pela Europa, Ásia e América no século XX, como bem aponta Balakian (2000). Ele cultiva o mistério, o vago, o indizível, o sonho, o invisível, seus poetas situam-se em "torres de marfim", à margem da sociedade, pois não encontram nela o seu lugar, sendo chamados de nefelibatas; por isso, agem como dandys, os quais chocavam a sociedade por sua maneira peculiar de se portar e de se vestir. Empregam o cromatismo, a sonoridade e o impressionismo para tornar sua poesia mais subjetiva. Não dizem, sugerem e esperam ser decifrados por seus leitores, pois, para eles, o poeta deve ser um vidente, ter o dom de captar os segredos ocultos em meio aos símbolos, à maneira do que se lê no poema “Correspondances" de Baudelaire (1857). O Simbolismo é um estilo, e sua denominação provém do vocábulo "símbolo", o que demonstra a complexidade das obras escritas sob a luz desse movimento. Os símbolos são, via de regra, arbitrariamente escolhidos pelo poeta para representarem suas ideias, devendo insinuar ao invés de descrever e esclarecer, um dos traços mais marcantes do movimento, e cabendo ao leitor interpretá-los. Balakian (2000) reflete sobre o uso dos símbolos e cita Maeterlinck que os definiu em efetivo e artificial: o primeiro tenta dar um aspecto humano à abstração, aproximando-se da alegoria; e o segundo tem um caráter inconsciente, transcende o pensamento do poeta e, ao ser utilizado, demonstra a genialidade do escritor. Balakian (2000, p.85-87) afirma:

Todos estes símbolos sugerem, com diferentes graus de intensidade, o desejo de fugir, não para uma nova morada, mas para longe de um lugar que é desagradável ao espírito poético.

Os simbolistas logo compreenderam que estavam se isolando em convenções poéticas e tentaram encontrar uma saída para elas. À medida que as paisagens interiores perderam seu caráter equívoco, o uso da cor e da sinestesia de tom e cor também perderam. As sinfonias em cinza, branco e azul rapidamente adquiriram correspondências precisas com determinadas emanações: vermelho para raiva, azul para imaginação, cinza para melancolia etc. 
Vale lembrar que, os textos de Laforgue aproximam-se mais da alegoria do que do símbolo, como aponta Moretto (1989). O poeta é mais alegórico porque não sugere, apenas, como a maioria dos simbolistas, ele repete ideias, combinações e conotações, ritmo e ironia. É importante definir que a alegoria transmite uma ideia abstrata sob a forma de cores, objetos, personagens ou situações que a explicam, traduzindo-a. Durant (1964, p. 9) define alegoria como “[...] tradução concreta de uma ideia difícil de compreender ou de exprimir de uma maneira simples". Quanto ao símbolo, Durant (1964, p. 11) diz que "o símbolo é, como a alegoria, recondução do sensível, do figurado ao significado, mas é também, pela própria natureza do significado inacessível, epifania, isto é, aparição, através do e no significante, do indizível”. Gomes (1994), ao tratar do símbolo, alega ter ele como característica não ser de todo arbitrário, pois possui um vínculo entre o significante e o significado e é, para os simbolistas, o núcleo da linguagem poética, um disfarce das ideias visando a combinar mundo sensível e mundo abstrato, evocando um estado de espírito cuja tradução demanda tempo e dedicação, já que o símbolo não é o objeto aludido, é tão somente sua representação.

O final do século XIX reviveu o helenismo e o culto a lendas anônimas da Idade Média, fato comum, na história europeia, quando existe uma crise na inventividade: procurase no passado algo que possa ser reanimado. A cultura helênica foi fonte de muitos símbolos também para os simbolistas, inclusive para Laforgue, que deu a eles um sentido bastante particular, como abordaremos mais adiante.

Contudo, o Simbolismo teve, na verdade, duas vertentes. Uma delas, menos estudada, a "coloquial-irônica", segundo denominação de Wilson (1967), é representada por Laforgue e Corbière (ambos foram incluídos no movimento simbolista por T. S. Eliot, que enxergou na obra deles uma poesia tão representativa quanto a de Baudelaire, Rimbaud, Verlaine e Mallarmé). Segundo Hamburger (2007), estes dois escritores discutiram, em suas composições, a obra inicial de Rimbaud, o spleen e o idéal de Baudelaire. A corrente na qual 
se inseriam, diferente da "sério-estética", que descrevemos anteriormente, não visava dar um sentido mais puro às palavras; ao contrário, pretendia colocar em confronto as torres de marfim e o mundo fin-de-siècle, porque se preocupava com o cotidiano e o tematizava. É nesta que se pautam os recursos utilizados nas composições de Laforgue. Este possui uma escrita inovadora, na qual se reconhece a presença da oralidade, da ironia, do humor e da crítica. Ele consegue unir o incompatível, aquilo que parece ser radicalmente diferente: o lirismo e o humor. Além disso, utiliza a paródia, a alegoria, o pastiche e a caricatura com o propósito de imbuir efeito às suas criações, apresentando um ideal poético que perpassa o discurso clownesco, minucioso e excêntrico.

Exemplificando essa dicotomia incomum, de palavras tão distantes que, unidas em seus poemas, provocam distintos efeitos de sentido, temos os seguintes versos do poema "Litanies des premiers quartiers de la lune", do livro L'Imitation de Notre-Dame La Lune, 1979, p. 19:

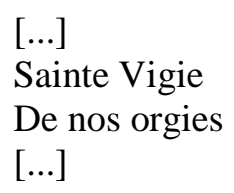

Neles, o poeta emprega o sagrado e o profano na mesma estrofe, lado a lado. Como é possível ser Santa a Vigia das orgias? Existe, aqui, uma quebra de expectativa, o que configura uma dissonância semântica.

Sobre a dissonância, Friedrich (1978) afirma ser ela a junção da incompreensibilidade e da fascinação, gerando tensão, objetivo visado nas artes modernas em geral, não somente na lírica. A obscuridade originada de seu uso é intencional, pois a dissonância não anuncia e nem prepara o leitor, surpreende-o. Por outro lado, a poesia vislumbrada apenas para eleitos, como ocorria com a maioria dos poetas da modernidade, não poderia ser facilmente interpretada, 
pois, como disse Baudelaire, "existe uma certa glória em não ser compreendido" (apud Friedrich, 1978, p. 16). A incompreensão eleva os poetas à condição de visionários.

Friedrich (1978) afirma que a poesia moderna pretende tornar-se uma criação autosuficiente, permitindo um leque de significações a partir do entrelaçamento de tensões, de universos distintos ou até mesmo divergentes. Resgata-se, para esse fim, o arcaico, o místico e o oculto, emparelhando-os com a simplicidade do cotidiano.

O poeta Jules Laforgue, além de dissonante, mantém, em inúmeros poemas, uma métrica precisa e rimada ricamente, traços que o ligam ao parnaso e ao simbolismo; não obstante, a escolha pela forma marcada, leva-o mais a criticar tais tendências do que exaltálas, visto que ele utiliza o ritmo em conformidade com a temática escolhida, a exemplo de suas litanies, nas quais emprega a fórmula dessa prece litúrgica traduzida pela métrica, uma invocação recitada ou cantada, repetitiva, entediante e monótona, repleta de queixas e pedidos. Os recursos que Laforgue utiliza não são, muitas vezes, originais; a forma como o poeta os emprega é que difere do usual. Nesse caso, nada melhor do que versos curtos e rimados para descrever a atmosfera de uma litania, como é possível entrever em "Litanies des derniers quartiers de la lune", do livro L'Imitation de Notre-Dame La Lune, 1979, p. 65:

Eucharistie

De l'Arcadie,

Qui fais de l'oeil

Aux coeurs en deuil,

$[\ldots]$

Infere-se uma crítica aos que acreditavam ser este tipo de poema o verdadeiro, como os parnasianos. Contra eles, ainda, ao longo de sua obra, Laforgue vai desenvolver e aprimorar seu verso livre, para falar, com frequência, do sonho, permeando o ideal e o inconsciente, embasado pelas teorias de Arthur Schopenhauer e de Karl Robert Eduard von Hartmann. Colocará em confronto o eu e a natureza, o sujeito e o discurso, através da 
linguagem. Segundo Scepi (2000), o sujeito, o eu-lírico de Laforgue é construído pela palavra que ele profere, pela linguagem, pela opacidade dos vocábulos e pelo eterno enigma se suas próprias contradições; assim, o poema apresentará o movimento dessa construção.

Conforme discorrem Strathern (1998) e Grojnowski (1988), de acordo com a filosofia de Hartmann, tudo pode ser explicado pelo inconsciente, o qual é incondicionado e absoluto, o criador do universo, não sendo possível explicá-lo por meio de nenhuma relação. Para o filósofo alemão, perder-se no inconsciente é uma alegria, bem como a ideia da fatalidade, do não querer viver e da renúncia ao individualismo. Hartmann calcou-se nos ideais de Schopenhauer, Hegel, Schelling e Nietzsche, postulando, a partir destes, uma concepção niilista de que retornar ao nada vale mais do que viver.

Com relação a Schopenhauer, ele foi bastante original e ficou conhecido como o filósofo do pessimismo, pois, dentre outras considerações, via o mundo como uma piada de mau gosto, indiferente ao destino do ser humano. O alemão defendia que o mundo que vemos é uma representação apoiada em uma Vontade universal que é cega e, por isso, provoca miséria, sofrimento e morte. A única maneira de nos libertarmos do individualismo e do egoísmo contidos nessa vontade é a compaixão pelos irmãos, obtida através da renúncia, da abnegação da vontade e do culto à estética das obras de arte, cuja expressão mais elevada, em sua concepção, era a música, seguida da poesia e da arquitetura. Uma forma possível de ver além do mundo das aparências, para ele, é olharmos para o nosso "eu" mais profundo, para dentro de nós mesmos. Seguindo a filosofia de Schopenhauer, além de Jules Laforgue, encontramos Wagner, músico de significativa influência para o movimento simbolista e que, adepto do pessimismo do filósofo alemão, testou variadas combinações artísticas.

Em acordo com estas filosofias, para quem deseja tentar escapar dessa Vontade universal, ou Vouloir-Vivre, a criação artística possui um papel muito importante, pois libera a inteligência desse jugo (GROJNOWSKI, 1988). O poeta é considerado um gênio, dotado de 
vontade e inteligência, agindo como louco ou sonâmbulo, na medida em que é movido por uma força que ultrapassa seu entendimento; a poesia surge como uma intuição, mesmo em sua musicalidade, no vocabulário e na rima, livre de toda intenção consciente.

Alguns temas encontrados nos poemas de Laforgue revelam o apreço do poeta pelo pensamento niilista de Schopenhauer, como a dor do mundo, o amor, a morte, a religião, o homem e a sociedade, e o livre arbítrio. Somando-se a isso, os textos schopenhaurianos encorajaram-no ao empirismo no que diz respeito à escrita, já que o seguimento imitativo de uma escola apenas satisfaz artistas medíocres, segundo Grojnowski (1988).

Este teórico, discorrendo a respeito das teorias de Hartmann, lembra que para este filósofo, o inconsciente está diretamente ligado à criação artística, pois o artista verdadeiro pode produzir uma obra original no momento em que recebe a inspiração como forma de força e a coloca em prática, mesmo não compreendendo perfeitamente o sentido do que está colocando no papel; seu trabalho é o de transmitir as ideias, apesar de, muitas vezes, não poder interpretá-las completamente.

O Inconsciente é uma terra desconhecida, uma espécie de Pasárgada onde o poeta deseja viver. Sua influência vai além das ideias, adentrando o campo da linguagem, promovendo a atividade do sujeito falante e determinando as condiçãoes da enunciação poética. Dessa forma, cria-se uma língua sem sintaxe, repleta de imagens exóticas, de relatos oníricos e hipnóticos, tocados pela oralidade. Isso justifica a recorrência do oral na poesia de Jules Laforgue, juntamente com o gosto pela bufonaria verbal.

O Inconsciente aparece, em Laforgue, como força, lugar e palavra. O funcionamento verbal de seus poemas revela um procedimento semelhante a um trampolim de ideias e palavras, aproximando os escritos da representação da voz humana, um encontro entre o ser e o dizer. O Inconsciente encontra na linguagem o ponto de aplicação que transforma a condição da poesia para além da inspiração e da mimesis. Laforgue aspira a uma palavra livre 
de todo modelo ou tradição, produzindo versos mais originais e criando um novo modo de dizer, polifônico e carnavalesco, trabalhado a partir de vozes discordantes, e livre da voga simbolista.

Laforgue, em um ensaio sobre Baudelaire, contido nas Oeuvres complètes daquele, revela muito do que acredita ser importante para um poeta e para a boa poesia. Alega que Baudelaire revelou a mulher esfinge, atitude que ele próprio tenta realizar em seus poemas com a inserção de figuras misteriosas como a esfinge egípcia e a Gioconda de da Vinci. Assim como o autor de Les Fleurs du Mal, também revela a repulsa pela modernização e pelo progresso das cidades, mostrando aspectos do repetitivo cotidiano oriundo desse crescimento; descreve o tédio e insere o bizarro e a enfermidade. Laforgue diz que Baudelaire trabalha as litanias e as lamentações, características que serão importantes em sua própria poética, uma vez que a litania será um dos temas mais utilizados nas composições do "coloquial-irônico", juntamente com as lamentações noturnas, já elucidadas pelo seu antecedente. 


\section{Jules Laforgue: vida e obra}

Jules Laforgue nasceu em Montevidéu, no Uruguai, em 1860, dia 16 de agosto, segundo os registros de batismo, e 20 de agosto, conforme documentos militares. Filho de Charles e Pauline Laforgue, aos seis anos de idade mudou-se com a família para Tarbes, na França. Sua vida foi marcada pelo tédio, o ennui, começando pela longa viagem de navio, de 65 dias, para chegar à França. Esta passagem é somada a sua timidez, aos problemas familiares e à perda da mãe ainda na adolescência:

[...] duas datas de nascimento, uma longa travessia do Atlântico, cheia de spleens e ocasos, e duas línguas - o francês e o espanhol - não são suficientes para explicar a poesia de invenção deste poeta que foi mestre de T. S. Eliot e Ezra Pound (BONVICINO, 1989, p. 15).

Em 1867, a família do jovem retorna ao Uruguai, ficando em Tarbes apenas Laforgue e seu irmão, Émile; ambos começaram a frequentar o Liceu de Tarbes, em 1869, permanecendo ali por alguns anos. Seus pais mudaram-se definitivamente para a França em 1875, e Laforgue, aos 16 anos, foi a Paris a fim de viver com a o pai, a mãe e os irmãos. Ingressou, nessa época, no Liceu Fontanes e, de acordo com registros históricos, o poeta era tomado de uma timidez incurável e sempre fracassava em seus exames orais. Em pouco tempo, falece a mãe, com 38 anos de idade, após sua décima segunda gravidez; depois de perder o bebê, Pauline ficou debilitada, adoeceu e morreu, o que foi um duro golpe para Laforgue.

Com a morte da mãe, o poeta perdeu a fé e começou a frequentar museus, bibliotecas, a andar pelas ruas de Paris e a assistir às aulas de Taine. Adquire gosto pelas artes, sobretudo a pintura. Dentro em pouco, tornou-se integrante do grupo dos Hidropatas, no Quartier Latin, onde se aproximaria dos três que se tornariam seus melhores amigos, Paul Bourget, Gustave Kahn e Charles Henry. 
Os Hidropatas eram um grupo de jovens escritores que se reunia a fim de discutir sobre arte e, ao mesmo tempo, analisar a produção artística um do outro. Nos cafés, jornais, cabarés ou salões onde se encontravam, liam em voz alta seus escritos para que os colegas pudessem exprimir seus comentários. Contudo, decorrido algum tempo, o grupo encerrou suas atividades; por conseguinte, alguns poetas passaram a fazer parte dos Hirsutes; outros reuniram-se em associações como os grupos da Rive Gauche e o Chat Noir.

Em 1879, o pai de Laforgue, já doente, retornou a Tarbes, deixando o filho em Paris apenas com uma irmã. Pela terceira vez, o jovem fracassa no exame francês baccalauréat. Em agosto do mesmo ano, o poeta publica seu primeiro poema conhecido, na revista $L^{\prime}$ Enfer, intitulado "La Chanson des Morts", datado de fevereiro de 1878 e sob o pseudônimo de Ouraphle. Em agosto e setembro, sob seu nome, publica mais três poemas na revista $L a$ Guêpe, todos estes, bem como o anterior, de cunho satírico.

No ano seguinte, o escritor começa a frequentar os meios literários franceses e, pela primeira vez, tem seu nome em uma revista, a La vie moderne, a qual tinha como redatorchefe o genro de Théophile Gautier. Inicia, então, seu livro Le Sanglot de la Terre, de influências verlainianas, pouco antes de articular a novela Stéphane Vassiliew.

Em 1881, o poeta francês começou a trabalhar como secretário do amigo Charles Ephrussi, diretor da Gazette des beaux-arts. Este, logo consegue que Laforgue seja nomeado leitor da imperatriz Augusta da Alemanha, esposa de Guilherme I. Destarte, mudou-se para Berlim e passou a viajar constantemente acompanhando a imperatriz. Essa época foi bastante importante para os escritos de Laforgue, pois o poeta entrou em contato, mais profundamente, com as artes e com diversos artistas, além de ser o período em que se dedicou a testar composições que fariam parte de suas Complaintes. Frequentou, na Alemanha, óperas, teatros e museus e, distante da vida de privações que tivera até então, apreciou o luxo e experimentou o ócio, tornando-se triste e melancólico. Durante os cinco anos que permaneceu no país, o 
poeta escreveu a maior parte de sua obra. Em 1883 recebeu uma notícia que abalou seu estado de espírito: o pai falecera; no entanto, não pode presenciar o funeral.

Dois anos mais tarde, ocorreu a publicação de Les Complaintes e, quatro meses depois, de L'Imitation de Notre-Dame La Lune. Aquela apresenta ausência de arquitetura interna e é tomada de um tom muito peculiar. Segundo estudo de Luís Carlos de Brito Rezende (1997, p.17), foi em Montmartre que Laforgue aprendeu a apreciar as canções populares, cantigas em casas onde havia serões no inverno, bem como as ouvidas em serestas de verão, as quais sugeririam a ele o tom de seus poemas, tanto populares e musicais quanto irônicos e refinados. Rezende apresenta uma descrição do que vamos encontrar nos poemas do escritor francês:

Entrando nos anos 1880, o radicalismo dessacralizador das letras que marcava os Hidropatas vai ser ligeiramente temperado com a passagem ao "Chat Noir", então em vias de tornar-se referência em Montmartre, ainda um vilarejo que diríamos, hoje em dia, "alternativo". Laforgue aprendeu ali a apreciar a canção popular, língua de elisões desafiando o metro codificado, mistura de tom gradiloquente e pobreza de meios de expressão, tudo isso resgatado por maciças doses de ironia. Refinando a receita, Laforgue vai catalisar seu projeto poético.

Laforgue trabalhava, nesse período, em suas Moralités Légendaires, obra escrita em prosa contendo a releitura de textos como Hamlet, de William Shakespeare e uma sátira da Salambô de Flaubert. Além destes, o poeta francês destaca Lohengrin, filho de Parsifal, o mito de Pan e de Syrinx, bem como Perseu e Andrômeda.

O ano de 1886 é marcado pela publicação, na revista $L a$ Vogue, de uma série de poemas de Walt Whitman, traduzidos por Jules Laforgue, somados à aparição do Concile Féerique; trabalhava também na composição das Fleurs de Bonne Volonté. É neste ano ainda que o poeta começa a ter aulas com uma jovem inglesa chamada Leah Lee, apaixonando-se e casando-se em pouco tempo. O casal mudou-se para Paris, no ano seguinte, e Laforgue publicou artigos em Le Figaro e na Revue Indépendante. Todavia, acometido pela 
tuberculose, caiu de cama, viveu apuros financeiros, tomou ópio para tentar suportar a infecção pulmonar e, por fim, faleceu no dia 20 de agosto, aos 27 anos, sendo enterrado no cemitério de Bagneux dois dias depois. Sua esposa, oito meses depois, teria o mesmo destino. Postumamente, são publicados dois volumes de autoria do escritor: Des Fleurs de bonne volonté e Derniers Vers, ambos no ano de 1890.

Moretto (1994, p.48) acrescenta que Jules Laforgue está pronto em 1880; é, tão cedo, um grande escritor e crítico. "Em primeiro lugar, Laforgue tem o estofo do crítico de arte: se o grande crítico da arte romântica foi Baudelaire, diz Jean Cassou, se o grande crítico do Cubismo foi Apollinaire, o grande crítico do Impressionismo foi Laforgue”. O jovem frequentou o grupo "hidropatas", a partir de 1879, no qual ficou em contato com jovens artistas e escritores de vanguarda, aqueles que seriam os "decadentes" e simbolistas dentro em breve:

Em menos de sete anos, nos diz Pascal Pia, Laforgue transpôs a distância que separa a prosódia tradicional de uma liberdade poética 'quase desconhecida antes dele'. Usa a paródia, a fantasia, desarticula versos e mitos anunciando a arte de Apollinaire e de Prévert (MORETTO, 1994, p. 57). 


\section{Recursos utilizados}

Ao referirmo-nos a Jules Laforgue, visualizamos algumas ferramentas importantes que marcam o seu fazer poético. Entre elas: a ironia, a oralidade, o apelo ao mundo greco-romano e o uso de recursos gráficos, estilísticos e lexicais. Cabe, aqui, discorrermos acerca de cada um destes recursos, não para conhecê-los simplesmente, mas para entender como eles convergem no sentido de auxiliar a construção da ironia.

\section{1 Ironia: complexidade poética}

A ironia é uma das constantes que marcam a obra de Jules Laforgue. Ironia é pressuposição, na medida em que sugere uma interpretação; ocupa a posição intermediária entre o sério e o ato de desmascarar; um contraste transparente entre a mensagem literal e a mensagem verdadeira. Traz consigo a franqueza, a zombaria, a sátira, a crítica e, na paródia, o escritor pode também utilizá-la como recurso. Mas, uma das dificuldades para compreendê-la é que, às vezes, ela figura nas entrelinhas do texto, sendo clara somente a quem a empregou. Segundo Duarte (2006), o autor não se coloca explicitamente em sua obra, ele adota a postura de um demiurgo e, apesar de todas as técnicas existentes, cada um tem sua própria maneira de fazer ironia. Por isso, juntamente com os traços da oralidade, ela torna a poesia de Laforgue ainda mais complexa, colocando obstáculos à sua compreensão.

Allemann (1978) aborda a ironia literária como um modo do discurso no qual existe uma diferença entre o que se diz e o que se pretende realmente dizer. Nesse caso, a ironia toma a forma do contrário, já que é declarado justamente o oposto do que se quer enunciar.

A ironia pode apresentar diversos sinais: os de pontuação, por exemplo, têm o objetivo de aguçar o efeito irônico - parênteses, exclamações, reticências, etc. Porém, quanto mais se 
renuncia a eles, mais irônico se torna o texto. O ideal será aquele cuja ironia possa ser pressuposta na ausência completa de todo sinal.

A ironia literária é como um equilibrista: fica entre os pólos, em uma posição intermediária, tentando não cair nem em uma fórmula corrente de seriedade, nem em banalidades e desmascaramentos crus. Existe, de um lado, a significação unívoca e séria da mensagem literal e também da intenção literal, e, de outro lado, a franca e zombeteira chacota, ou, segundo os critérios literários, a mais pura sátira, na qual o objetivo literário não tem uma simples função assertiva.

Para Sperber e Wilson (1978), uma noção retórica mais geral, no que diz respeito à ironia, é a de sentido figurado. O problema é que grande parte dos enunciados são ambíguos, comportando um número elevado de significados. A desambiguização é (muitos concordam) uma tarefa do contexto; no entanto, nem sempre isso é tão simples. Exemplo: O tempo está esplêndido. Esta é uma frase que traz problemas: como saber se o interlocutor está expressando o seu pensamento ou se quer dizer o contrário? Por que não o diz diretamente? Qual a intenção em exprimir uma mensagem pelo seu contrário? Nesse caso, não é apenas a ideia que deve ser levada em consideração, mas em conjunto com a intenção em transmiti-la. Por isso interpretar a ironia torna-se complexo, em virtude dos muitos subentendidos que pode apresentar.

Sperber e Wilson (1978) relatam ainda que, na concepção clássica, ironia e paródia eram classificadas como mecanismos diferentes: mudança de sentido naquela, imitação nesta. Hoje, entretanto, utilizamos a "paródia irônica", uma mistura de ironia, no campo semântico, e paródia como recurso estrutural.

Há várias formas de ironia segundo Muecke (1978) divididas em: cômica, satírica, trágica, niilista e paradoxal. A cômica remete ao significado primevo da palavra, o de ser risível. A satírica aprova a censura ou a desaprovação do sujeito antipático ironizado, objeto 
da zombaria. A trágica é aquela em que o sujeito simpático ironizado percebe a censura ou repreensão sobre ele. A niilista faz uma ligação necessária entre autor e público e o desligamento satírico é que neutraliza ou domina a simpatia com relação ao sujeito ironizado. Por fim, a ironia paradoxal denota que tudo é relativo, ela não reflete valores humanos como as outras; autor e público misturam ou alternam identificação e desligamento; o triunfo cômico e o fracasso trágico se neutralizam, ou a norma satírica varia constantemente.

Hutcheon (1978) também teoriza sobre a ironia, e mais, fala da relação entre ironia e paródia. Reporta-se a vários autores que fazem uso desses dois recursos conjuntamente, a fim de exemplificar as possibilidades de utilização de ambas as ferramentas em um mesmo bloco textual. Define ironia como um tipo de processo de atualização: nem ela, nem a paródia podem explicitar exclusivamente a reprodução de uma ação; devem ser, sobretudo, ações que seguem estratégias destinadas a permitir ao leitor interpretar e avaliar.

A paródia, muitas vezes, é confundida com a sátira, apesar esta possuir, geralmente, um cunho moral em suas intenções, o que não é regra para a paródia. Entretanto, a sátira pode utilizar a paródia como dispositivo estrutural.

O termo paródia vem do grego parodos que significa contracanto, uma forma literária sofisticada. Parodiar não implica, necessariamente, ironizar; pressupõe, sim, uma sobreposição de vozes. No momento em que é empregada a paródia, consegue-se enxergar dois textos: o original - parodiado - e a paródia feita a partir dele. Tal procedimento é diferente, contudo, do pastiche o qual é unívoco, a imitação perfeita de modo a fazer o leitor acreditar que está lendo um texto do autor imitado.

Jules Laforgue serve-se da paródia irônica como recurso para refinar sua ironia. É possível percebê-la, por exemplo, no poema "Complainte de Cette Bonne Lune", do livro Les Complaintes, 1979, p.44: 
Dans l'giron

Du Patron,

On y danse, on y danse,

Dans l' giron

Du patron,

On y danse tous en rond.

[...]

Sous l'plafond

Sans fond,

On y danse, on y danse,

Sous l'plafond

Sans fond,

On y danse tous en rond.

Estes refrões são paródias da conhecida cantiga folclórica francesa "Sous le pont d'Avignon", paródias que chegam bem perto do pastiche:

Sous le pont

D'Avignon,

On y danse, on y danse,

Sous le pont

D'Avignon,

On y danse tous en rond.

$[\ldots]$

Notam-se, neste poema, traços irônicos. Na cantiga, as pessoas dançam sob a ponte d'Avignon, versos que são parodiados e transformam-se em uma dança no colo do patrão, no poema laforguiano; esta versão, transpondo o irônico, fica no limite do satírico, pois envolve julgamento moral. Já no segundo refrão do poema, o eu-lírico dança sob o teto profundo, ou seja, sob o infinito. Esta temática do céu, permeada pelo culto do infinito, dos astros e principalmente da lua, como será visualizado em todos os poemas lunares analisados, está relacionada a uma ironia crítica embutida nas palavras utilizadas que atacam o Simbolismo sério-estético.

Laforgue combina de maneira bastante particular recursos linguísticos e literários. Percebe-se que a ironia e a paródia estão assaz presentes em sua obra; aliás, Laforgue trabalha 
tanto a paródia que consegue aproximá-la da caricatura. Mas a ironia é o recurso central dos poemas do escritor; ora de forma sutil, surgindo inesperadamente, ora declarada abertamente, como em “Nuitamment”, do livro L'Imitation de Notre-Dame La Lune, 1979, p. 51:

Ô Lune, coule dans mes veines

Et que je me soutienne à peine,

Et croie t'aplatir sur mon coeur!

Mais, elle est pâle à faire peur!

$[\ldots]$

O eu-lírico inicia um diálogo com a lua transmitindo a falsa intenção de exaltá-la, dizendo que ela corre em suas veias; temos a impressão de que leremos um típico poema simbolista. Contudo, inesperadamente, surge o verso /Mais elle est pâle à faire peur/. A palidez da lua não possibilita a criação de uma atmosfera de deslumbre, e sim de zombaria.

Hutcheon (2000, p.37) diz que a ironia apresenta arestas e são estas que permitem haver diferentes interpretações para um mesmo período. Para ser compreendida, ela depende de uma relação entre escritor e interpretador; é, por conseguinte, arriscado comunicar-se ironicamente, já que a compreensão depende da interpretação correta do receptor da mensagem. Às vezes a ironia é muito particular, sendo necessário analisar o espaço entre o dito e o não dito. Além disso, existem as chamadas "comunidades discursivas": "[...] a ironia acontece porque o que poderia ser chamado de "comunidades discursivas" já existe e fornece o contexto tanto para o emprego quanto para a atribuição da ironia”.

Além da superposição de comunidades discursivas, contextos experienciais e discursivos diferentes geram possibilidades de interpretação (Hutcheon, 2000, p.38): “[...] quanto mais o contexto é compartilhado, em menor quantidade e menos óbvios são os marcadores necessários para sinalizar - ou atribuir - ironia”. A desambiguização, nesses casos, nem sempre pode ser feita através do contexto, pois a própria ironia é causadora de ambiguidade. 
A autora analisa a capacidade da ironia em irritar, quando nega as certezas do ser humano ao desmascarar o mundo em que vivemos com a ambiguidade. A ironia pode atacar, zombar, humilhar, embaraçar, excluir, provocar, criticar, enfim, irritar o objeto irônico, seu alvo; o fio da ironia é cortante e, muitas vezes, envolve o lado afetivo, movendo e sendo movida por sentimentos, sensações, reações; tem os nervos à flor da pele. A emoção está envolvida tanto ao zombar, quanto ao distanciar-se, ao menos na intenção de fazê-lo. Ela provoca estas sensações tanto ao ser compreendida e interpretada quanto ao ser perdida e, por isso, não compreendida pelo ironizado.

De acordo com a autora, em uma escala decrescente no que diz respeito à emoção, a ironia pode ser: agregadora, atacante ou assaltante, de oposição, provisória, autoprotetora, distanciadora, lúdica, complicadora ou reforçadora. Porém é, acima de tudo, um processo comunicativo, semanticamente relacional, inclusiva e diferencial. Relacional quando opera não só entre os significados, mas entre as pessoas; inclusiva quando é antífrase; diferencial na explicação do problema entre a ironia e outros tropos como metáfora e alegoria.

Com relação ao sentido irônico, Hutcheon (2000) afirma que ele permanece em fluxo no texto, não sendo fixo. Só é possível obtê-lo por meio da combinação do dito com o não dito que, juntos, formarão um terceiro sentido: o irônico. A ironia está diretamente ligada à polissemia, à soma de dois significados, não necessariamente opostos, para formar um significante, o qual faz parte do signo irônico.

Hutcheon também descreve a relação existente entre ironista e interpretador: ambos possivelmente julgam a capacidade intelectual um do outro quando estão diante de uma mensagem irônica, isto porque para se construir ou entender a ironia é necessário ter atenção e perspicácia. 


\section{2 Oralidade}

O emprego de marcas de oralidade ocorre com frequência nos poemas de Jules Laforgue. Historicamente, por um longo período de tempo, as histórias e os feitos dos grandes heróis foram cantados e contados, e desse modo tornavam-se conhecidos de geração em geração. Desde a infância, as pessoas tomam contato com essa literatura oral através das lendas, das anedotas, dos provérbios, das cantigas de roda, das fábulas, dos casos, das quadras, do folclore, dos mitos em geral, da literatura de cordel etc. É um contato primeiramente oral que se faz antes mesmo da alfabetização.

A oralidade, conforme descreve Urbano (2000), compreende não só os aspectos linguísticos sonoros e verbais, mas também todos os recursos visuais, que auxiliam e completam os primeiros, integrando a língua falada. Isso implica a escrita de uma série de adaptações técnicas artísticas, criativas e ortográficas, às vezes interessantes, outras vezes danosas à comunicação, com o intuito de tentar transcrever as expressões do enunciador. Por isso, para o entendimento da mensagem, é necessário considerar os recursos linguísticos, paralinguísticos e extralinguísticos.

Em se tratando de oralidade, a enunciação tem importante papel, sendo realizada por meio do emprego de uma ou de múltiplas vozes. Daniel Grojnowski é, hoje, o maior estudioso da obra de Laforgue e da oralidade. Em seu artigo Jules Laforgue: Spectacle et Oralité, ele tece importantes considerações a respeito do assunto. A oralidade é comumente visualizada em peças de teatro, diálogos dentro da narrativa ou em expressões do eu-lírico; é expressa através da entonação, da pontuação, etc. Contudo, pode ser observada em todos os tipos de texto impresso, sendo, muitas vezes, alcançada de maneira enigmática, de forma a procurarmos quem é o enunciador. Laforgue deixa clara em sua obra a escolha por termos e expressões ligados à tradição oral. 
Há dois modos de expressão no que diz respeito à oralidade: um enunciado ou uma voz que se faz transparente - transparência da mensagem - e um enunciado marcado por uma voz, uma pessoa ou uma personagem provocando efeito de presença e relação entre enunciador e receptor desconhecidos. Na língua falada, a enunciação é dependente do contexto que, no caso de Laforgue, é amplo e complexo; faz-se necessário um minucioso trabalho investigativo a fim de conhecer e interpretar as expressões com as quais deparamos. É grande o número de obras, de autores e de figuras que são citados, de nomes relacionados a mitos, a lendas, a canções, entre outros. O contexto dos poemas de Laforgue é psicossociológico; recheado, portanto, de intertextualidade, dos conhecimentos do autor, uma forma pessoal de fazer ironia, permeada de criatividade.

Urbano (2000) diz que muitos escritores, desde a literatura medieval e seguindo pelos mais diversos momentos históricos, utilizaram a linguagem coloquial como ferramenta. Mas nem todos conseguiram produzir um coloquial elaborado, criando novos efeitos de sentido, como o fez Jules Laforgue.

Em se tratando deste poeta, devemos nos lembrar de que ele frequentava os salões, os cabarés, e reunia-se com outros escritores para lerem suas composições, em voz alta, esperando a aprovação ou a crítica dos demais. Assim, quando lemos muitos de seus poemas, imaginamos ouvir a voz do eu-lírico que conversa; Laforgue, por vezes, escreve como se estivesse falando, conversando com alguém ou com ele mesmo. Temos ainda de nos ater a outros recursos, além da voz: o estilo, o tom, a originalidade; é a soma disso que traz a expressiva singularidade de sua obra. O sujeito da oralidade de Jules Laforgue é construído ora através de um componente teatral, ora através de um jogo do dito e do escrito, ora através da polifonia.

É possível levantarmos, ainda, uma questão interessante quanto às marcas de oralidade na obra do poeta, quando analisamos a construção do texto laforguiano. Um escritor pode 
planejar o que vai escrever, diferentemente de quem fala que, muitas vezes, não realiza uma prévia reflexão daquilo que pretende dizer, utilizando, pois, uma sequência de palavras inadequadas ou pouco eficientes, tornando-se incompreensível ou inconveniente. Por diversas vezes, esta é a impressão que se tem ao ler determinados poemas do escritor francês, na medida em que ele utiliza determinadas palavras simplesmente para ironizar, para criar sonoridade, sem necessária atribuição de sentido, pelo prazer em realizar a bufonaria verbal, como afirma Hamburger (2007, p. 74): “À zombaria de si mesmo e ao coloquialismo ele acrescentou certo prazer na bufonaria verbal, como na dedicatória de sua coletânea a Paul Bourget e seu trocadilho entre "pour cent" [por cento] e "pur sang" [puro-sangue]". Isso se confirma com o que dizem Bradbury e McFarlane (1989, p. 171): “A consciência irônica da linguagem é um convite não a renovar nossa fé na linguagem, mas a desconfiar dela, admitir que ela pode ser pura superfície, puro verbalismo". No entanto, essa bufonaria é intencional, a exemplo do que se lê no poema "Stérilités", do livro L'Imitation de Notre-Dame La Lune, 1979, p. 57 :

\section{Stérilités}

Cautérise et coagule

En virgules

Ses lagunes des cerises

Des félines Ophélies

Orphelines en folie.

Tarentules de feintises

La remise

Sans rancune des ovules

Aux félines Ophélies

Orphelines en folie.

Sourd aux brises des scrupules,

Vers la bulle

De la lune, adieu, nolise

Ces félines Ophélies

Orphelines en folie !... 
Esterilidade é não produzir nada intelectualmente, ser estéril, não procriar; tem relação com a ineficácia, a inutilidade e a esterilização. Ao longo do poema, convencemo-nos de que foi esta a ideia que o poeta quis passar ao leitor, pois este poema se revela semanticamente ineficaz e repleto de termos que o comprovam, apresentando-se rico em sonoridade e em jogo de palavras, buscando produzir ecos sonoros, ao invés de significados. Percebemos, então, a métrica e a rima trabalhadas na composição e na representação do tema escolhido.

A primeira estrofe inicia-se com os verbos cauterizar e coagular, no imperativo, a primeira marca de oralidade, por remeter a ordens, as quais se realizam por meio da fala. São duas ações que convergem para a esterilidade, e vão anunciar que esta acontecerá no poema, ela será realizada nas vírgulas, ou seja, no texto:

\section{Cautérise et coagule \\ En virgules

Em seguida, surge a figura da órfã Ofélia, personagem de Hamlet, de Shakespeare, representada em sua loucura. O eu-lírico do poema, misógino como o protagonista do livro de Shakespeare, joga com as palavras ligando-as à vida estéril de Ofélia, a qual não produziu nada intelectualmente, nem deixou descendentes; teve apenas a loucura por companhia, esta uma expressão da esterilidade do ser, a perda completa da sanidade. Tais ideias reúnem-se em um refrão criado a respeito da personagem, o qual será repetido no decorrer das estrofes, apresentando pequenas modificações intencionais:

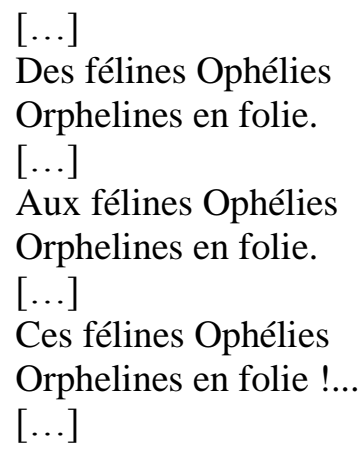


Na segunda estrofe, há um jogo sonoro com os vocábulos feintises e ovules, estes, mais uma vez, ligados à Ofélia estéril, agora chamada de tarântula fingida /Tarentules de feintises/. Na terceira, o eu-lírico, surdo aos escrúpulos, ou seja, louco, ruma em direção à lua, astro que é a expressão máxima da esterilidade e que, neste contexto, vem ao encontro das considerações tecidas: um ser estéril irá buscar refúgio na esterilidade lunar.

O que se pode perceber é uma demonstração de metapoesia: a estrutura ligada ao tema, o jogo de palavras e de sonoridade; mesmo a ausência de sentido é planejada, a fim de exprimir a noção de esterilidade. A rima é um recurso pródigo dos humoristas e, no poema, é bastante trabalhada em seus versos de sete sílabas poéticas, além dos três decassílabos quebrados na sétima sílaba, a fim de acompanhar os demais, deixando três versos de três sílabas poéticas cada como ênfase temática das estrofes: /En virgules/, /La remise/ e /Vers la bulle/. A assonância sufixal é aqui marca recorrente, dividindo, sonoramente, três blocos temáticos: esterilidade ligada à dissimulação; esterilidade textual ilustrada pela personagem shakespeariana; menções a Ofélia estéril:

1. Cautérise, cérises, feintises, remise, bises, nolise;

2. Coagule, virgule, tarantule, ovules, scrupules, bulle;

3. Felines, Ophélies, orphelines, folie.

Há um jogo entre a $1^{\mathrm{a}}$, a $2^{\mathrm{a}}$ e a $3^{\mathrm{a}}$ pessoas, não se identificando ao certo quem fala e a quem fala. Esta relação de pessoas e de palavras demonstra também a oralidade do poema, já que, na fala, não se planeja o discurso, não havendo meio de apagar o que foi dito e dizê-lo novamente, diferentemente do que ocorre na escrita.

A personagem de Shakespeare aqui inserida é apresentada de maneira diferente do que se visualiza em Hamlet, já que recebe adjetivação diversa da caracterização utilizada pelo escritor inglês. Vale ressaltar que a figura feminina, nos textos laforguianos, é vista como 
ambiciosa e fingida, isenta de ingenuidade. É esta misoginia que possibilita, neste poema, o uso de termos qualificativos de uma Ofélia felina, louca e estéril: /Des felines Ophélies/, /Orphelines en foliel, /Tarentules de feintises/, /Sourd aux brises des scrupules/.

O poeta trabalha com a sonoridade das palavras sem a preocupação de ligá-las necessariamente através de uma relação semântica, causando a impressão de que os vocábulos foram emparelhados aleatoriamente no papel. Cria, assim, uma espécie de teoria da composição, permeada de oralidade e de humor, apresentando o poema como a própria alegoria da esterilidade, um jogo de fonemas aparentemente desconexos que, na esterilidade relacional entre eles, propagam a mensagem pretendida pelo poeta, trabalhando a esterilidade de Ofélia, da mulher em si, por meio da misoginia, e da lua, alvo de inúmeras considerações com este enfoque crítico.

Jules Laforgue aproveita a tradição oral, que se compõe de mitos, lendas, crenças e canções populares, em diversos poemas de sua obra. Um dos construídos sob esta temática, exemplo interessante em que ele se serve dessa tradição, é sua "Complainte de Cette Bonne Lune”, retirada do livro Les Complaintes, 1979, p. 51, também permeada pela ironia, estruturalmente auxiliada pela paródia: 


\section{Complainte de Cette Bonne Lune}

On entend les Étoiles:

\section{Dans l'giron}

Du Patron,

On y danse, on y danse,

Dans 1' giron

Du patron,

On y danse tous en rond.

— Là, voyons, mam'zell' la Lune,

$\mathrm{Ne}$ gardons pas ainsi rancune;

Entrez en danse, et vous aurez

Un collier de soleils dorés.

— Mon Dieu, c'est à vous bien honnête, Pour une pauvre Cendrillon;

Mais, me suffit le médaillon

Que m'a donné ma soeur planète.

- Fi! votre Terre est un suppôt

De la Pensée! Entrez en fête;

Pour, sûr, vous tournerez la tête

Aux astres les plus comme il faut.

— Merci, merci, je n'ai que ma mie, Juste que l'entends gémir!

- Vous vous trompez, c'est le soupir Des universelles chimies!

- Mauvaises langues, taisez-vous! Je dois veiller. Tas de traînées, Allez courir vos guilledous!

— Va donc, rosière enfarinée!

Hé! Notre-Dame des gens soûls,

Des filous et des loups-garous!

Metteuse en rut des vieux matous!

Coucou!

Exeunt les étoiles. Silence et Lune. On entend:

Sous l'plafond

Sans fond,

On y danse, on y danse,

Sous l'plafond

Sans fond,

On y danse tous en rond. 
Nota-se, claramente, a musicalidade da primeira e da última estrofes, espécie de refrão em que a música é mais acentuada do que no restante do poema. Entretanto, há outros recursos empregados, advindos da linguagem falada, que completam a atmosfera de oralidade sugerida pela paródia da cantiga popular francesa Sous le pont d'Avignon:

\section{Dans l'giron}

$[\ldots]$

Neste primeiro verso temos o emprego da elisão gráfica expressa pelo l' que marca, ortograficamente, a pronúncia do artigo. O mesmo ocorre com o verso Sous l'plafond da última estrofe, que registra a oralidade.

Outra forma que podemos considerar como marca da linguagem informal, reforçando o l'giron é o on y danse. A partícula on designa a terceira pessoa do singular e, nesse caso, é a forma utilizada na língua falada e coloquial. Nesse poema, temos um caso de manifestação oral feita por meio do diálogo entre a lua e os que dançam a ronda. O travessão introduz as falas do diálogo e as interjeições: Fi! Hé! Coucou!, além de construções que reproduzem formas orais como ma mie, mam'zell' e o uso do verbo l'entends sem o sujeito expresso são marcas que, segundo Saint-Gérand (2000), são utilizadas para expressar tensões psicológicas e poéticas travadas no enunciador. Além disso, há traços de oralidade no uso do imperativo, indicando fala. Exemplos: taisez-vous, allez, ne regardons pas, entrez. O vous denota os interlocutores: de um lado a lua e, de outro, os que dançam e a contemplam. Já com relação à tradição oral, a presença dos contos de fada, bem como de elementos tradicionais e mitilógicos, representados aqui por Cendrillon e pelos loups-garous, comprova a escolha destes termos para compor o poema.

Percebe-se em todo ele o tom de paródia que existe desde o início, com o retorno à espécie de refrão que remete à velha cantiga Sous le pont d'Avignon. Todo ele é permeado por referências irônicas a temas que compõem o repertório poético em torno da lua. No entanto, 
Laforgue, mestre em surpreender, provoca quebra de expectativa e constrói a dissonância ao parodiar elementos do próprio Simbolismo e usar, ironicamente, o tema lua, tão recorrente entre os simbolistas "sério-estéticos".

No refrão final, podemos notar a musicalidade e a disposição dos versos semelhantes aos da primeira estrofe, fechando a ronda e o poema. Ambos insistem na oralidade, já que foram implantados para ser cantados, não para acalentar, mas sim para zombar. A paródia irônica é que dá o tom a essa complainte; o lamento a essa boa lua que ilumina quem dança esses passos Sob o teto sem fundo, segundo os termos de Muecke, emprega uma ironia satírica, pois exprime julgamento de valor, desaprovação e zombaria.

\section{30 mito e sua relação com a ironia}

A recorrência dos mitos e de nomes greco-romanos é de grande importância na poética de Jules Laforgue. O poeta faz uso constante do mundo clássico para enfatizar, justificar e validar uma das principais características de seus poemas: a ironia.

Laforgue utiliza a menção a obras, autores, mitos da tradição oral, entre outros, para fazer com que o leitor precise realizar um aprofundado trabalho investigativo, uma característica da modernidade literária. A poesia se torna mais complexa, repleta de recursos que permitem a intertextualidade; o autor, como nunca, necessita do leitor para decifrar suas composições, mas de um leitor ideal que conheça os termos aos quais o poeta faz alusão para dar vida às imagens e às comparações por ele pretendidas.

Como lembra Zacharakis (1995), os mitos gregos inspiraram artistas e dramaturgos, proporcionando matéria para os escritores que figuraram na história, desde a época clássica até a atualidade. E, no século XIX, o Simbolismo se atém às figuras míticas com o intuito de renová-las. Como podemos ler nos vários artigos da revista Vortex, Laforgue não procura refletir o mito, busca alterá-los até sua dessacralização, aderindo assim ao metafísico, na 
medida em que busca outras concepções da realidade, da existência e da essência do mundo, não as míticas.

A revista Vortex surgiu a partir de uma associação formada por professores e escritores, leitores e estudiosos de Jules Laforgue, após um colóquio em Tarbes, em 1994. A proposta era a de difundir a obra do poeta e de propor, anualmente, uma reflexão crítica da problemática de seus escritos. A Universidade de Liège acolheu esta associação e, em 1997, surgiu o primeiro volume sob o título de Vortex, turbilhão, nome bastante apropriado para o turbilhão de ideias e recursos encontrados na obra do escritor. Há três volumes da revista em circulação: no 1 - Spectacle et Oralité, publicado em 1997; n² 2 - Laforgue et le Mythe, em 1998; nº 3 - Les Complaintes, 2000.

Retomando a questão do mito, este é um fenômeno difícil de definir, pois muitos fatos sem explicação, como os relacionados à existência humana, crenças e costumes tornam-se mitos. Normalmente, representam relações entre os seres e o mundo; mas o que não se pode contestar é que ele está diretamente ligado à palavra. Em grego, inclusive, o termo mito já foi sinônimo de logos, palavra. Apresenta-se forte, cristalizado e duradouro, mesmo com o decorrer dos séculos, a ponto de muitos mitos clássicos chegarem até nós, ocidentais, através dos tempos e ainda serem conhecidos e estudados atualmente. Zacharakis (1995, p. 17) continua:

A palavra mito procede do grego mythos, que é uma palavra ligada ao verbo mytheuo, que significa "crio uma história imaginária". Mito, então, é uma criação imaginária, que se refere a uma crença, a uma tradição ou a um acontecimento. Mito também é uma história imaginária ou alegórica, falada ou escrita em obra literária que encerra um fundo moral. 
É importante lembrar o que nos diz Raul Fiker (2000, p. 30) com relação aos mitos, a fim de entendermos o processo criativo de Jules Laforgue:

Os grandes mitos básicos que caracterizam uma época, se chegam a revelar algo dela é a partir do modo como a disfarçam, pois a preferência por uma máscara específica ao invés de outra qualquer pode ser mais reveladora que o próprio rosto descoberto.

As construções frasais de Laforgue e a escolha de vocábulos para suas composições impressionam os estudiosos. Uma das grandes curiosidades de sua obra é o uso bastante peculiar do universo clássico com o intuito de dessacralizar, desmistificar e desviar burlescamente os mitos greco-romanos, acentuando a ironia expressa.

Laforgue consegue, em seus poemas, fazer uso de diversas combinações de recursos linguísticos e literários, tendo a citação do mundo greco-romano como um complemento essencial à construção da crítica e da ironia. Um interessante exemplo disso é o poema “Dimanches no 2", contido no livro Des Fleurs de bonne volonté, 1979, p. 164, no qual o poeta se serve de inúmeros nomes míticos, misturando-os a menções de escritores lidos e admirados na época em que escrevia, criticando-os e, mais uma vez, utilizando a misoginia como recurso ironizante: 


\section{Dimanches $\mathrm{n}^{0} 2$}

Le Dimanche, on se plaît

À dire un chapelet

À ses frères de lait.

Orphée, ô jeune Orphée!

Serials des coriphées

Aux soirs du fleuve Alphée....

Parcifal, Parcifal!

Étendart virginal

Sur les ramparts du mal....

Prométhée, Prométhée!

Phrase répercutée

Par les siècles athées....

Nabucodonosor!

Moloch des âges d'or

Régissez-nous encor?...

Et vous donc, filles d'Ève,

Soeurs de lait, soeurs de sève,

Des destins qu'on se rêve!

Salomé, Salomé!

Sarcophage embaumé

Où dort maint Bien-Aimé....

Ophélie toi surtout

Viens moi par ce soir d'août

Ce sera entre nous.

Salammbo, Salammbo!

Lune au chaste halo

Qui laves nos tombeaux....

Grande soeur, Messaline!

Ô panthère câline

Griffant nos mousselines....

Oh! même Cendrillon

Reprisant ses haillons

Au foyer sans grillon....

Ou Paul et Virginie,

Ô vignette bénie

Des ciels des colonies....

- Psyché, folle Psyché,

Feu-follet du péché,

Vous vous ferez moucher! 
Primeiramente, vale ressaltar que Laforgue escreveu muitos poemas batizados dimanches, os domingos. Domingo é o dia da inação, do tédio, do descanso, no regime capitalista. Traduz-se, através dele, uma forte crítica à sociedade, ao materialismo, ao progresso que gera miséria e decadência. O domingo de Laforgue não é visto como um dia de lazer e sim como um dia de extremo tédio, de pessimismo e de cansaço. Podemos notar, nestas linhas, como o escritor se vale de características e do espírito de revolução dos decadentes, intimamente ligados à temática dominical.

Na primeira estrofe, vemos o domingo ligado à religião por meio da referência à oração do terço. O eu - lírico denota, no segundo verso, que vai dizer seu terço e o faz. Atentando para a forma, percebemos que o poema é a recriação satírica da própria reza do terço. São treze estrofes de três versos cada: a primeira é a menção ao que vai ser feito; as doze seguintes fazem o papel do Pai-nosso inicial (coincidentemente, ou não, os primeiros nomes citados são masculinos), das dez Ave-Marias e do Glória final de um terço cristão.

Em cada estrofe, ainda, é possível notar um esquema de apresentação. O primeiro verso começa sempre com o nome do mito ou da obra citados em tom de vocativo - como a Ave-Maria, por exemplo - aludindo à oralidade. O segundo faz considerações a respeito do nome abordado no primeiro, e o terceiro tece a ironia. As exclamações e as interrogações, além das reticências, expressam marcas de oralidade, como bem indicou Saint-Gérand (2000) em seu estudo.

$\mathrm{Na}$ segunda estrofe, há referência a Orfeu e Alfeu. Ambos os nomes não se assemelham apenas na rima; referem-se a mitos gregos. Orfeu era poeta e músico, e tudo acalmava com sua lira. Apaixonou-se, por Eurídice, mas a jovem faleceu. Orfeu, por meio da melancolia de sua música, consegue chegar ao mundo dos mortos e convencer Hades e Perséfone a deixá-lo levar a amada novamente até o mundo dos vivos. Hades aceita conceder seu desejo; porém, em virtude da curiosidade de olhar para o rosto da amada, Orfeu acaba 
perdendo-a novamente, pois não se voltar para trás até deixar o Hades foi uma exigência feita pelo deus dos infernos. Posteriormente, o músico é assassinado e, finalmente, encontra-se com a amada no mundo inferior.

Alfeu é o nome de um rio da Grécia. Segundo a mitologia, Alfeu apaixonou-se pela ninfa Aretusa e a perseguiu até a Sicília por dentro da terra, onde acabou se unindo a ela que havia sido metamorfoseada em uma fonte.

Aparece também a figura do corifeu, o chefe do coro no teatro antigo. O corifeu é a pessoa que mais se distingue, que mais se destaca, é o chefe, o cabeça, o mestre.

Essas figuras não são citadas aleatoriamente. Orfeu e Alfeu são personagens transgressores, que não aceitaram a situação em que se encontravam, por terem perdido as amadas. Este espírito de contestação vem reforçar a crítica ao mundo moderno.

$\mathrm{Na}$ terceira estrofe, o eu-lírico evoca Parsifal. Este foi herói de romances de cavalaria da Idade Média e, no século XIX, título de uma ópera em três atos do compositor alemão Richard Wagner, com libreto do próprio, no qual desenvolve uma afirmação dos poderes do bem sobre o mal. Percebemos, nessas duas estrofes, como Laforgue pode ser enquadrado entre os simbolistas, para os quais a música tem sua significativa relevância, e como está diretamente relacionada com a poesia.

Prometeu aparece na quarta estrofe. O titã grego é uma figura transgressora, revolucionária, apropriada às ideias e recursos inovadores de Laforgue e dos movimentos nos quais ele se insere. Prometeu foi aquele que roubou o fogo divino de Zeus e o entregou aos homens, dando-lhes a possibilidade do conhecimento. É um mito assaz forte e abordado por diversos autores de diferentes movimentos literários, por ser uma das figuras mais contestadoras.

$\mathrm{Na}$ quinta estrofe, encontramos personagens ligadas à religião, tema insinuado na primeira estrofe e que está sempre presente nos poemas laforguianos. Nabucodonosor foi o rei 
da Babilônia, muito conhecido pelos seus grandes feitos: a conquista de Judá, a destruição de Jerusalém e a construção dos Jardins Suspensos da Babilônia. Na Bíblia, é um personagem soberbo e orgulhoso. E Moloch, na tradição bíblica, é o nome do deus ao qual os amonitas, uma etnia de Canaã, sacrificavam seus recém-nascidos jogando-os em uma fogueira. Também é o nome de um demônio na tradição cabalística. Deparamos, então, com personagens de poder e de desordem que, justamente pela sua história, ironizam os mitos e a tradição religiosa.

Na sexta estrofe aparece Eva, outra transgressora em busca do conhecimento de todas as coisas, assim como Prometeu. Trata-se da primeira mulher da humanidade, segundo a tradição judaico-cristã e foi quem corrompeu Adão dando-lhe a maçã que a ela foi oferecida pela serpente; é a causadora do pecado original, em busca da sabedoria suprema. Sua inserção vem reforçar a ideia de revolução, de não aceitação das regras estabelecidas. Favorece a visão da religião permeada de orgulho, de poder e de desobediência.

No sétimo terceto, é encontrada uma figura bíblica muito polêmica: Salomé. Sobrinha do rei Herodes, foi responsável por decapitarem João Baptista - influenciada pela mãe que mantinha um relacionamento extraconjugal com o rei. Tinha 16 anos de idade quando dançou na presença de Herodes, fundador de Tiberíades, e pediu-lhe, em seguida, a cabeça do profeta em uma bandeja de prata.

Investigando as figuras, é possível estabelecer uma relação entre elas e a temática do poema, já que este é crítico, não podendo ser melhor ilustrado senão pela inclusão de personagens tão transgressores. $\mathrm{O}$ domingo do tédio e a crítica à modernidade são reforçados pelos nomes escolhidos e inseridos neste poema. Como já dito, Laforgue utiliza as figuras míticas a fim de dessacralizá-las, mostrar o lado transgressor e dar validade a sua ironia. Criticar o mundo moderno com figuras do mundo antigo é um modo interessante de fazer 
ironia; criticar o mundo moderno ironizando as figuras clássicas faz parte do estilo laforguiano, autor de uma ironia dupla.

Na oitava estrofe é citada Ofélia, personagem de Hamlet, já encontrada e analisada em "Stérilités". Na nona estrofe, encontramos Salammbô. Essas obras de Shakespeare e de Flaubert, respectivamente, são muito criticadas e ironizadas por Laforgue, pois são admiradas e exaltadas pelos simbolistas da tendência sério-estética, para tomarmos a divisão de Wilson (1967). No décimo terceto, é a vez de Valéria Messalina, esposa do rei Cláudio, mulher cruel, ambiciosa e de péssima reputação. Somando-a às demais figuras femininas retratadas em “Dimanches $n^{\circ} 2$ ", podemos visualizar a misoginia, mais uma vez, do eu-lírico, tratando as mulheres como estéreis de ingenuidade e ambiciosas.

Laforgue utiliza inclusive a figura da Cinderela ("même Cendrillon") na estrofe seguinte, personagem pertencente à tradição oral. No poema, diferentememte do que se pode identificar na leitura do conto tradicional, ela também faz parte da atmosfera da ambição feminina, bem como da transgressão dos personagens. Trata-se de uma moça pobre e excluída que burla as regras, buscando a ascensão social por meio do amor do príncipe.

Na penúltima estrofe, surgem Paul e Virginie, casal de personagens de um romance de mesmo título, de Bernardino de Saint-Pierre, bastante popular no final no século XVIII, tendo por cenário as Ilhas Maurício, que era então colônia francesa. Os dois adolescentes emocionaram por ignorarem naturalmente (como a natureza) o mal. Esta bondade, ligada à estrofe anterior onde estão Cinderela e Parsifal, de Wagner, é empregada satiricamente.

E, por fim, na última estrofe, há um apelo à razão. Nela encontra-se a figura mítica de Psiquê, cujo pecado da curiosidade e da dúvida que a torna escrava de Afrodite (vous vous ferez moucher), realizando trabalhos impostos pela deusa, a fim de tentar reconquistar o Amor (Eros) perdido. Psiquê, dotada de extraordinária beleza, vivia feliz em um palácio, mas jamais vira a face do amado; acreditava que este fosse um monstro. Certa noite, influenciada pelas 
palavras invejosas das irmãs e pela sua própria curiosidade, retira o capuz do amado, mesmo tendo prometido a ele que não o faria nunca e, embasbacada diante da beleza de Eros, fere-o com uma gota do azeite quente da lamparina que carregava, acordando-o e fazendo-o conhecer a transgressão à promessa. A bela Psiquê aparece reforçando, portanto, a trangressão tão contrária ao exemplo que deram aqueles personagens.

Esta crítica é feita por meio de artifícios inovadores, da ironia e do humor, da criação e da crítica, da inserção de figuras, personagens, obras, autores e mitos quase sempre utilizados pelo poeta de maneira transgressora, parodiando o uso que deles fizeram mesmo os simbolistas. Em meio a essa atmosfera, o mundo greco-romano faz-se presente: ironizando e sendo ironizado.

É importante frisar que este é apenas um dos possíveis caminhos a serem tomados em direção à análise dos escritos laforguianos. Além disso, a inserção deste "Dimanches no 2", teve o objetivo de analisar exclusivamente o uso das figuras míticas, populares e literárias. Assim como os poemas aqui interpretados, Laforgue possui muitos outros de temáticas diversas, incluindo a dos domingos e a da lua. Os domingos são menções críticas à decadência, um apelo ao tédio que este dia simboliza para o poeta. E a lua remonta ao Simbolismo "sério-estético" que a cultuava e é uma crítica feita ao movimento e às convenções poéticas levadas ao extremo, isolando os poetas da sociedade. Para Laforgue, a sugestão e a complexidade não trilham os caminhos da reclusão e sim da reflexão. Apesar de odiar a sociedade, o poeta não se esconde, privando-se de seu convívio; ele está no âmbito social para poder melhor criticá-lo, destrói as convenções poéticas para se fazer compreendido, sem deixar de ser complexo. Cabe ao leitor atento seguir esta trilha rumo a interpretações e julgamentos. 


\section{4 Recursos gráficos, estilísticos e lexicais}

Compreendemos quando Favre (1986) observa que Laforgue surpreende seus leitores a todo instante com algumas combinações inesperadas: é a dissonância, o encontro de tons distintos sendo utilizado como recurso que visa surpreender e que produz um efeito desagradável e incômodo. Soma-se a isso a criação significativa de novas palavras, todas repletas de significado e também produzindo a dissonância. Moretto (1978) confirma tais dizeres ao lembrar que Laforgue possui uma sintaxe desconjuntada, utiliza gírias e neologismos em meio ao humor e à ironia.

Como exemplo desses artifícios, tomemos a seguinte estrofe do poema "Cas redhibitoire (Mariage)", do livro Des Fleurs de bonne volonté, 1979, p. 169:

\footnotetext{
Ah! mon âme a sept facultés!

Plus autant qu'il est de chefs-d'oeuvre, Plus mille microbes ratés

Qui m'ont pris pour champ de manoeuvre. $[\ldots]$
}

O eu-lírico diz que possui muitos talentos, mais do que obras-primas, e que tem mil micróbios fracassados que o tomam como campo de manobras. Neste trecho, percebemos o jogo com a linguagem utilizado habitualmente por Laforgue, evocando a dissonância semântica ao associar vocábulos de diferentes campos semânticos como talentos, obrasprimas e vermes.

Laforgue tem consciência viva da natureza do espaço e do tempo, espaço que é indefinido, e tempo que passa com monotonia, pois há com frequência a sucessão de momentos que se repetem em seus escritos, comprovados pelo emprego de termos e de dados recorrentes. Exemplificando, tomemos o Grand Pardon, ou Dia do Perdão, grande festa judaica anual que visa ao arrependimento e às orações, a qual ocorre no início do ano judaico e tem duração de dez dias, culminando com o Yom Kipur. Kipur, na raiz hebraica, significa 
expiação, o castigo que cobre o homem devido a seu ato perverso. O Grand-Pardon faz com que o homem jejue e reflita, tentando tornar-se uma pessoa melhor. Essa tradição aparece em alguns poemas de Jules Laforgue, como em "Petites misères de mai", do livro Des Fleurs de bonne volonté, 1979, p. 147:

On dit: 1'Express

Pour Bénarès!

La Basilique

Des gens cosmiques!...

Allons, chantons

Le Grand Pardon!

$[\ldots]$

Existem alguns poemas de Laforgue que foram intitulados "Pequenas Misérias", as quais podem ser de maio, de julho, de agosto ou de outubro, de inverno ou de outono (estes poemas podem ser lidos integralmente nos anexos), abordando geralmente lamentações e expiação. O poema em questão tem uma dicção compacta, estrofes de dois versos cada, atribuindo um ritmo rápido que lembra o clima sufocado das ladainhas. É um poema elíptico que mostra a peregrinação dos fiéis a Benarés, cidade santa da Índia, para pedir bênçãos e agradecer. Os trens citados remetem à Revolução Industrial do século XIX, época em que os homens lutavam pelo domínio do tempo e do espaço. Eles eram comuns nas pinturas dos impressionistas, muito apreciados por Laforgue, em decorrência da técnica utilizada: pinceladas soltas capturando impressões, variações das cores, não reproduzindo meramente o real. O poeta, ao ironizar o progresso, por meio da figura do meio de transporte que remete à modernização, juntamente com o ritual religioso, ironiza também as crenças, como a do Dia do Perdão, as canções e as peregrinações. Desse modo, nota-se uma ironia dupla, ou seja, ao mesmo tempo em que o Grand Pardon auxilia a crítica ao progresso é também usado para ironizar a própria religiosodade. Essa dupla ironia é um recurso muito particular do escritor, que faz dela sua grande ferramenta de crítica e zombaria, igualmente presente no poema 
"Litanies des premiers quartiers de la lune", do livro L'Imitation de Notre-Dame la Lune, 1979, p.19:

\author{
Lune bénie \\ Des insomnies, \\ [...] \\ Sois l'Ambulance \\ De nos croyances! \\ Sois l'édredon \\ Du Grand-Pardon!
}

Neste excerto, há uma espécie de humor irônico que resulta da aproximação de palavras de caráter sacro e outras laicas. A lua como ambulância, socorrendo-nos; como edredom, envolvendo-nos e libertando-nos dos pecados, faz parte da ironia dupla do poeta: ao mesmo tempo em que ironiza as crenças religiosas ilustradas, mais uma vez, pelo GrandPardon, ironiza os cultos à lua, sempre excessivamente utilizada pelas literaturas romântica e simbolista.

Ao brincar assim com as palavras, as tradições e os valores, Laforgue emprega fantasia, malabarismo e acrobacias verbais, fazendo com o verso o que bem quer. Apaixonado pela pureza e pelo ideal, não se cansa de descrever os aspectos sujos, miseráveis e repugnantes da realidade. Sonhador e sentimental, irônico e bufão, exprime sempre uma tristeza incurável, uma decepção incessante, um deleite melancólico em sua poesia extremamente complexa. O tédio constitui a experiência fundamental que suscita a criação poética e para tentar fugir dele, mergulha no mais profundo do Inconsciente, no nada e também na dissonância.

Observamos, novamente, que a dissonância, traço moderno por excelência, relacionase a sentimentos e representações, fazendo com que as impressões fugidias e as emoções mais profundas, a espontaneidade e a zombaria se misturem e determinem contrastes inesperados. Laforgue não cessa de praticar a ruptura utilizando diversos níveis de linguagem e 
misturando-os muito intimamente. A aliança das palavras permite acentuar a impressão de rompimento, como acontece com os oxímoros e os neologismos criados. Um exemplo de associação de palavras semanticamente diferentes é o termo dissonante violuptés, uma mistura de violence e volupté, plaisir (violência e prazer). A dissonância pode ser expressa pelo uso do itálico / L'art de tout est l' Ainsi soit-il;/, "Pierrots V", do livro L'Imitation de Notre-Dame la Lune, p. 32; pela métrica, misturando-se ritmos e estilos, versos longos e versos curtos em tom de contraste, etc, como em "Pierrots", do livro L'Imitation de Notre-Dame la Lune, p. 33:

$[\ldots]$

Elle disait, de son air vain fondamental :

«Je t'aime pour toi seul! » -oh ! Là, là, grêle histoire;

Oui, comme l'art ! Du calme, ô salaire illusoire

Du capitaliste l'Idéal !

A dissonância pode ainda ser expressa através do uso dos parênteses, caso do poema "Pierrots II", do livro L'Imitation de Notre-Dame la Lune, p. 30:

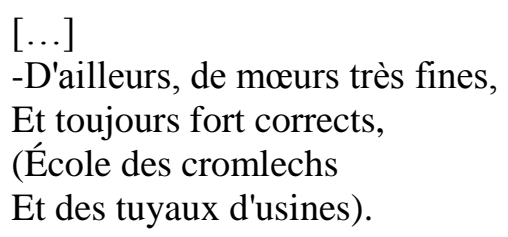

Esses recursos mostram a originalidade do autor em questão, sua genialidade e sua faceta de poeta humorista. Pelo que descrevemos nesses parágrafos é possível perceber de que maneira Laforgue cria, em suas obras, a estética da surpresa.

Sua originalidade está, sobretudo, em uma concepção de mundo na qual é possível ressaltar a experiência sobrenatural, a realidade situada além dos cinco sentidos, a mistificação verbal e a analogia entre poesia e música. Quanto a isso, Pound (1976) considera Laforgue um dos criadores da poesia logopaica, na qual o intelecto dança entre as palavras estabelecendo equilíbrio entre as imagens e a música. Toda sua poesia é um jogo de simulações e dissimulações. O poeta faz um serviço de limpeza, de higiene, de purgação e de 
crítica; explodiu na língua francesa para a "desmoralização de uma rotina ética e estética e para preparar o terreno de um mundo novo (ainda por vir)" segundo Faustino (2004).

O que o distingue, particularmente, ainda, é o fato de que, como Tristan Corbière, por exemplo, ele percebeu que, com o emprego de símbolos, os simbolistas estavam se afastando, isolando-se em convenções poéticas. Por conseguinte, tanto em seus poemas quanto em suas Moralités Légendaires, Laforgue utiliza a paródia para ironizar concepções simbolistas e decadentistas servindo-se da filosofia pessimista de Arthur Schopenhauer e da filosofia do Inconsciente de Karl Robert Eduard von Hartmann, ambas já focalizadas neste trabalho. Sobre isto disse Ezra Pound (1976, p.121):

É ele um artista incomparável. É nove décimos crítico, tratando, na maior parte das vezes, de poses e clichês literários, que toma como assunto; e - o que é mais importante quando pensamos nele como poeta - transforma-os em veículos para a expressão de suas próprias emoções pessoais, ou de sua própria imperturbada sinceridade.

Seus procedimentos poéticos podem ser encontrados em poetas que o seguiram, entre os quais os nossos modernistas Carlos Drummond de Andrade e Manuel Bandeira. Aproximam-se também dos mecanismos empregados por Laforgue os poemas de dois simbolistas brasileiros: Pedro Kilkerry (1885-1917) e Marcelo Gama (1878-1915). Laforgue exerceu influência sobre grandes autores como Cummings, Willianns, Crane, Dylan Thomas, além de Eliot e Pound. Este (1976, p.120) apontou toda a importância que deve ser creditada a Laforgue "talvez [...] o mais sofisticado dos poetas franceses".

Os autores da modernidade buscavam revolucionar a linguagem, limpá-la por meio do uso do sentido etimológico, da conotação, das combinações inesperadas, entre outros procedimentos. Laforgue atinge o mais alto grau na revolução de seu vocabulário.

Mário Faustino (1976) diz ainda que o poeta é um jovem de gênio preparando o mundo para o que virá; é, portanto, um poeta do século XX, mais do que do XIX, um 
visionário figurando entre os poetas maiores. Segundo o autor, a poesia de Jules Laforgue é um "sistema de autodefesa psicológico" (1976, p. 135), em função das desilusões inferidas pelo amor; é um ato de purgação, de limpeza e de crítica. E quanto à forma, diz Faustino (1976, p. 136):

\begin{abstract}
Laforgue examina, seleciona, corta, amputa. Pega o que tem de bom em Verlaine (a preocupação com a Melopéia) e acrescenta-lhe o que lhe faltava: o bom verbalismo (Pound), a boa logopéia, a "prosa" poética e a "poesia" prosaica. Diversifica como ninguém antes (inúmeros predecessores, sobretudo na França: Baudelaire, Rimbaud...), a linguagem poética: vocabulário científico, gíria... E faz o que quer com o verso tradicional: não respeita nem o "ímpar" de Verlaine nem o "par" dos outros; cria seus próprios ritmos e, finalmente, juntamente com Gustave Kahn, cria, ou recria, na França, o chamado vers libre, ou polirrítmico. Predecessores sob esse aspecto: Rimbaud, Rhine, Whitman, muita gente.
\end{abstract}

Através de Jules Laforgue, é possível enxergar o universo decadente do período em que escrevia; o mundo industrial instalando-se e instigando as críticas do poeta. Estas recaem não apenas sobre o ritmo acelerado das cidades, mas também sobre aqueles que decidem isolar-se da sociedade, sentindo-se alheios ao mundo, refugiando-se em torres de marfim.

Laforgue, diferentemente de outros poetas, desaprova esse isolamento, critica os que se perdem em convenções poéticas, e, como solução, inova, modifica os moldes vigentes inventando uma nova linguagem e, consequentemente, uma nova poesia, utilizando sua bagagem intelectual para fazer crítica. Sendo assim, precisa de um leitor que desenvolva um atento trabalho de investigação e reflexão.

Com isso, notamos como a poesia de Laforgue é elástica, precisa e, ao mesmo tempo, condensada, e sua capacidade condensadora, seu caráter detalhista e elíptico, tornam-na documento vivo dos sentimentos e anseios de uma época e do espírito das pessoas.

Melo Neto (1994, p. 724) recorda ainda que enquadrar um poeta em regras vigentes é tarefa demasiadamente árdua, pois cada escritor tem seu modo particular de produzir, afirmação que se encaixa ao fazer poético do escritor francês: ele está inserido nos 
movimentos decadentista e simbolista, mas critica-os, ironiza-os. Assim, a erudição, as leituras, as preferências e a imaginação de Laforgue tornam trabalhoso o objetivo de descrever sua poética e complexo o intento de analisá-la.

\subsection{Formas da língua e singularidades da escrita}

Jules Laforgue, segundo Saint-Gérand (2000), aplica mecanismos que se repetem em sua poesia. Estes justificam tanto sua aproximação com o popular e o oral, quanto a inovação da maneira de versejar. Em um capítulo sob este mesmo título, o estudioso levanta questões morfológicas, gráficas, lexicais e estilísticas quanto ao uso da língua francesa e de termos estrangeiros na poética do escritor francês.

Primeiramente, Saint-Gérand (2000) discorre sobre as palavras escolhidas por Laforgue, as quais, segundo o autor, estabelecem relação com a subjetividade, lúdica ou trágica, segundo modalidades de enunciação próprias a cada contexto. Desse modo, os vocábulos que compõem os poemas do escritor francês podem possuir significados bastante singulares, dependendo do contexto em que foram utilizados. Além disso, Jules Laforgue exercita mecanismos combinatórios inusitados, tanto morfológicos quanto sintáticos. Quanto a estas questões de morfo-sintaxe, podemos destacar algumas constantes nos poemas do escritor. Dentre elas está o uso do plural feito com o sufixo -als, caro aos simbolistas e decadentes do século XIX. Segundo a regra, os adjetivos terminados em - al fazem o plural aux, o qual é deixado de lado. Destarte, sentimental torna-se sentimentals.

Somando-se aos termos franceses, encontramos palavras ou expressões estrangeiras das quais o poeta se serve, provocando, em algumas ocasiões, efeito de discordância ou dissonância devido à gama de conotações. São termos latinos, gregos, ingleses, italianos e orientais, principalmente os de origem judaica e indiana, como por exemplo Ex-voto, Nihil, Idem e Vortex. 
Em virtude desse léxico diversificado, é preciso que o leitor demonstre um conhecimento enciclopédico, a fim de interpretar o sentido e o valor de cada palavra. Consulta a dicionários, busca de significados variados, estudo da etimologia serão hábitos dos que se aventurarem a investigar o universo laforguiano. São termos técnicos, populares ou coloquiais, onomatopeias, palavras emblemáticas, que provocam dúvida quanto ao significado no texto e que tornam a poesia de Laforgue ainda mais complexa.

Quanto à oralidade, esta pode ser expressa por meio de diversos recursos, como já abordado neste trabalho anteriormente: uso de termos da linguagem coloquial, da elisão gráfica do l'e, de interjeições, exclamações e interrupções, de refrões, antífonas ou versos repetidos e da desorganização dos esquemas fônicos das frases, os quais podem ser visualizados na explanação realizada do poema "Complainte de Cette Bonne Lune".

Já com relação à sintaxe, existem construções que podem provocar diferentes efeitos de sentido no contexto em que são introduzidas: o infinitivo, adjetivos funcionando como epítetos, atributos ou apostos, formulações interrogativas ou negativas, reiterações, indefinição advinda de plurais ou de termos que seguem em direção à abstração, verbos com diferentes complementos e formas pronominais expletivas.

Quanto ao estilo do poeta, Saint-Gérand (2000) discute técnicas como o emprego de palavras contendo o -e caduco (as quais possibilitam a criação de rimas femininas), o enjambement, a escolha de formas inusitadas dos versos, sobretudo as ímpares, a libertação da rima e a supressão de sinais de pontuação.

Tais considerações serão levadas em conta e colocadas em prática nas análises a serem feitas no próximo capítulo. 


\section{L'Imitation de Notre-Dame la Lune: Algumas Análises}

Este livro de poemas, de 1885, faz parte da obra "madura" de Laforgue; possui tanto textos rimados e metricamente elaborados quanto viagens pelo verso livre. Como o próprio título revela, é perpassado majoritariamente pela temática da lua, ironicamente apresentada na medida em que se relaciona com seu culto por parte dos românticos e simbolistas "sérioestéticos", assim denominados por Wilson (1967); trata-se de uma crítica ao movimento e às convenções poéticas levadas ao extremo, que isolam os poetas da sociedade. Também a figura do Pierrô aparece com frequência, e fortemente ligada à imagem da lua. Essa associação reforça a ironia trabalhada em torno do astro estéril, criando uma atmosfera de contrários e aproximações.

L'Imitation de Notre-Dame la Lune foi composto no início de 1885 e publicado em novembro do mesmo ano, alguns meses depois de Les Complaintes. Mostra, segundo Pascal Pia (1979), mais unidade do que os volumes anteriores, reunindo poemas mais afinados com a ironia e o humor, e embasados em duas temáticas principais: a brancura da lua e o Pierrô.

Somando-se a elas, a obra expõe as pequenas misérias, as locuções e as litanias, três manifestações de monotonia provocada pela atmosfera de repetição nelas contidas, a qual é usada como ferramenta para compor o universo irônico e estéril dos poemas.

A lua, segundo o Dicionário de Símbolos (1995), possui correlação com o simbolismo do sol, pois, além de não ter luz própria, sendo apenas reflexo da irradiação solar, apresenta diferentes fases conjuntas com mudanças de forma, sugerindo transitoriedade. O astro é o primeiro morto, tendo em vista que durante algumas noites desaparece e reaparece em seguida, ressurgido em brilho. A lua é um símbolo da passagem da vida à morte e da morte à vida, o que favorece visões dicotômicas: evoca beleza ou medo, fecundidade ou esterilidade, bem como frieza. Muitos povos imaginam que ela seja o lugar dessa passagem da vida à 
morte, reservado somente a privilegiados. Vista por eles como mentirosa, retrata um ambiente onde não somos nem humanos, nem divinos.

As fases da lua inspiram um simbolismo lunar, calcado em questões transcendentais como a morte e a ressurreição. As marcas lunares instigam a imaginação dos povos, os quais lhes atribuem formas variadas de animais ou até traços do rosto humano, rendem cultos ao astro e dão continuidade a lendas e mitos.

De acordo com a astrologia, a lua situa-se em uma zona noturna que pode ser comparada ao nosso inconsciente, em sua relação com impulsos instintivos. Estes sinalizam o primitivo que habita os homens, fazendo parte da personalidade, penetrando a imaginação, o sono, a fantasia e a sensibilidade, agindo, dessa maneira, como duplo.

Em L'Imitation de Notre-Dame la Lune, encontram-se os poemas posteriores às complaintes, porém igualmente repletos de oralidade. As canções populares que influenciaram em demasia o tom e a sonoridade de Les Complaintes estão presentes em certas modulações, no que diz respeito a rimas, métrica e refrões.

O título desta obra, Imitação de Nossa Senhora a Lua, é bastante sugestivo. Primeiramente no que diz respeito à imitação, um indício de possíveis paródias, paráfrases ou recorrentes composições rítmicas. A ação de imitar a lua propõe a construção de versos irônicos, uma vez que o astro, para o poeta, é a expressão máxima da esterilidade, a qual será integrada à arquitetura de alguns versos, exemplificados neste trabalho pelo poema "Stérilités", sobre o qual se conclui a intenção de bufonaria verbal e de esterilidade semântica como meio de enriquecer a sonoridade. Comparar a lua estéril à Virgem Maria confere ao livro um ar de sátira, de zombaria não somente do astro, mas das crenças religiosas da tradição judaico-cristã. 
Laforgue agrupa as palavras de forma inesperada, o que demanda, em muitos poemas, uma compreensão inversamente proporcional ao esperado, permitindo a criação de novos sentidos para as frases, produzindo conotações e gerando possibilidades de interpretação.

Por conseguinte, faz-se necessário esclarecer que este estudo indica apenas um dos possíveis caminhos a serem tomados em direção à análise dos escritos laforguianos. Como os poemas aqui interpretados, Laforgue possui muitos outros de temáticas diversas, incluindo a da lua. Cabe ao leitor atento seguir esta trilha rumo a interpretações aprofundadas.

Iniciaremos com algumas considerações a respeito dos poemas enluarados. Abaixo um exemplo da visão irônica da lua, do livro L'Imitation de Notre-Dame La Lune, 1979, p.51:

\author{
Nuitamment \\ Ô Lune, coule dans mes veines \\ Et que je me soutienne à peine, \\ Et croie t'aplatir sur mon coeur! \\ Mais, elle est pâle à faire peur! \\ Et montre par son teint, sa mise, \\ Combien elle en a vu de grises! \\ Et ramène, se sentant mal, \\ Son cachemire sideral, \\ Errante Delos, nécropole, \\ Je veux que tu fasses école; \\ Je te promets en ex-voto \\ Les Putiphars de mes manteaux! \\ Et tiens, adieu; je rentre en ville \\ Mettre en train deux ou trois idylles, \\ En m'annonçant par un Péan \\ D'épithalame à ton Néant.
}

Primeiramente, visualizemos o poema em função do título do livro: L'imitation de Notre-Dame la Lune. A lua é comparada a Nossa Senhora, à Virgem; seria uma veneração? Como essa composição mostrará, estamos diante de um livro irônico desde seu título, pois se 
trata de veneração que remete, de fato, ao culto lunar simbolista, o qual é aqui ironizado. Através do diálogo do eu-lírico com o céu, ou melhor, com a lua, o poeta tece sua crítica àqueles que praticam o culto ao astro estéril.

Ao contrário de proferir elogios à lua, o eu-lírico dirige-se a ela ironicamente, a exemplo dos versos 4 e 6 , os quais zombam a brancura, o brilho e a palidez lunar tão apreciados pelos poetas do romantismo e do simbolismo:/Mais, elle est pâle à faire peur/; /Combien elle en a vu de grises!/.

Algumas expressões comprovam a imagem degradada que Laforgue cultiva em relação à lua, caso do já mencionado poema "Stérilités". Exemplo disso são os termos nécropole, ex-voto, Putiphars e Néant. Ex-voto é uma palavra de origem latina aplicada ao universo religioso cristão. Denomina uma placa contendo fórmulas destinadas a serem utilizadas na confissão, como forma de exame de consciência. Está diretamente ligada, no poema, à figura de Putifar, eunuco e general do exército egípcio, segundo a Bíblia, que comprou José, o qual fora vendido pelos próprios irmãos. Ele confiou a José sua casa e suas finanças, tamanha era a afeição e confiança que lhe devotava. Certa vez, a esposa de Putifar, encantada pelo rapaz, tentou seduzi-lo. Não obtendo êxito, entregou ao marido a capa de José alegando ter sido assediada por ele, que foi preso em seguida, conferindo ao general a imagem de marido traído. Este episódio é citado no poema, inclusive na menção da capa, manteaux, símbolo da suposta traição.

Os termos nécropole e Néant sugerem o nada do ser, do qual veio e para onde retornará. Néant demonstra a influência, segundo Saint-Gérand (2000), da filosofia pessimista de Schopenhauer; o nada não tem propriedade.

Laforgue critica também as torres de marfim, o isolamento dos poetas que recusavam o convívio social ou que se emolduravam em convenções poéticas, retratados alegoricamente na figura da lua que se sente mal e segue para sua cachemira sideral: 
$[\ldots]$

Et ramène, se sentant mal,

Son cachemire sideral,

$[\ldots]$

A lua é símbolo de esterilidade pois, sem luz própria, é reduzida apenas ao reflexo do sol. O poeta simbolista, ao cultuar a lua, imita também sua infertilidade, seu nada errante. Como ela, torna-se estéril, ou seja, preso às convenções, isolando-se em sua cachemira sideral das “torres de marfim”; transforma-se em um oráculo de sua própria degradação.

"Nuitamment" é composto por oito dísticos de oito sílabas poéticas em cada verso. As rimas acontecem internamente, em cada dístico, sendo um de rimas masculinas e outro de femininas, alternadamente. Assim como as rimas, as vozes do poema são divididas: os quatro primeiros dísticos são um jogo entre a $2^{\mathrm{a}}$ e a $3^{\mathrm{a}}$ pessoas do singular, enquanto os outros quatro estão na $1^{\text {a }}$. O eu-lírico inicia sua fala dialogando com a lua, direta ou indiretamente; porém, no meio do poema, muda o discurso e começa a falar dele próprio, afirmando que entrará na cidade se auto-anunciando com um canto ao nada da lua. $\mathrm{O}$ verbo ramener (reconduzir) aparece nesse momento indicando que o discurso mudará de direção.

A visão que o eu-lírico nutre pela lua é a de um astro pálido, de má aparência e coberto de sombras. Ao desejar que ela faça escola, está embutida uma observação irônica do poeta com relação ao simbolismo, adepto do culto ao astro.

Laforgue busca figuras na Bíblia, e igualmente na tradição clássica, aqui representada por Péan, deus grego com poderes de cura, diretamente ligado a Apolo. Todas elas atendem a seu propósito maior: ironizar. Ao mesmo tempo em que são ironizadas, servem de ferramentas para a zombaria da lua; aproximando um personagem cristão de um pagão, igualando-os no tratamento, confundindo-os em seu propósito de, também, provocar surpresa, Laforgue consegue chocar seu leitor, atingindo-o tanto pela temática quanto pela dissonância. 


\section{Litanies des premiers quartiers de la lune}

Lune bénie

Des insomnies,

Blanc médaillon

Des Endymions,

Astre fossile

Que tout exile,

Jaloux tombeau

De Salammbô,

Embarcadère

Des grands Mystères,

Madone et miss

Diane-Artémis,

Sainte Vigie

De nos orgies,

Jettatura

Des baccarats,

Dame très lasse

De nos terrasses,

Philtre attisant

Les vers-luisants,

Rosace et dôme

Des derniers psaumes,

Bel œil-de-chat

De nos rachats,

Sois l'Ambulance

De nos croyances!

Sois l'édredon

Du Grand-Pardon

(L'Imitation de Notre-Dame la Lune, 1979, p.19) 
Como mencionado anteriormente, litania é uma palavra que vem do grego e significa uma prece litúrgica monótona, entediante e repetitiva. É a primeira menção à religiosidade e à prática da oralidade no poema, atestada pela citação dos últimos salmos. O ritmo condensado, expresso por versos curtos, com quatro sílabas poéticas cada, rimados (rimas masculinas e femininas, alternadamente, sugerindo diálogo) e agrupados em dísticos, corrobora esta litania da lua. A palavra quartiers remete às suas fases, mas também significa, em francês, grau de nobreza. Imagina-se que exaltará o astro, crença que cai por terra logo nos primeiros versos, quando percebemos o seu desejo de ironizar em torno do tema.

O vocabulário utilizado mistura palavras do universo religioso (bénie, Sainte Vigie, rachat, Grand-Pardon) e termos do domínio pagão (Endymions, Diane-Artémis), dissonantes. São recorrentes as alusões à cor branca, ao brilho e ao formato circular da lua. A luz fica acentuada, pois se trata de uma lua em quarto crescente, anunciado no título. Os trechos a seguir relacionam termos, como Blanc médaillon (branco medalhão) e baccarats (bacará cristais), que remetem à forma circular, além de compor versos luzentes:

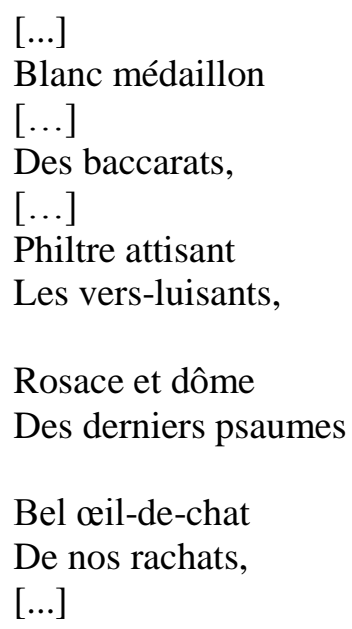

A figura da lua é ironizada em todo o poema, mostrada como fóssil, astro antigo e ultrapassado da mesma forma que a cultura clássica até então cultuada pelos simbolistas sérioestéticos. Do alto, ela vigia as orgias daqueles que caminham na terra, não por cultuá-la, mas 
por insônia. O vocábulo orgies evoca cenas que se aproximam das práticas sociais e individuais da vida noturna.

A lua é chamada ironicamente Madone e, também, oeil-de-chat (olho de gato), que redime os que a contemplam. Igualmente é nomeada embarcadouro dos grandes mistérios, os do passado, dos gregos, como é possível inferir por meio dos personagens citados da mitologia. Os endimiões, por exemplo, cultuavam a lua, o que nos leva a crer na zombaria à cultura grega aqui exposta, uma vez que ela era acessível apenas a iniciados. Isso não quer dizer que o poeta não contemplasse os iniciados com seus poemas, porém não se prendia a convenções poéticas.

A figura de Salambô, muito criticada por Laforgue, bem como seu escritor Gustave Flaubert, mais uma vez é colocada em sua poesia por ser uma obra muito apreciada pelos simbolistas em vista das pedrarias e do exotismo nela contidos.

Este é um poema humorístico, jogando com o religioso e o laico ou pagão. Trabalha, de maneira anacrônica e zombeteira, com a forma redonda da lua, com personagens que têm ligação com ela e que pertencem ao domínio do sagrado, do ritual, do profano e do cotidiano. Por detrás de algumas aproximações, revela-se o desejo de rir da lua excessivamente abordada pelos românticos e simbolistas. 


\section{Litanies des derniers quartiers de la lune}

Eucharistie

De l'Arcadie,

Qui fais de l'œil

Aux cœurs en deuil,

Ciel des idylles

Qu'on veut stériles,

Fonts baptismaux

Des blancs pierrots.

Dernier ciboire

De notre Histoire,

Vortex-nombril

Du Tout-Nihil,

Miroir et Bible

Des Impassibles,

Hôtel garni

De l'infini,

Sphinx et Joconde

Des défunts mondes,

Ô Chanaan

Du bon Néant,

Néant, la Mecque

Des bibliothèques,

Léthé, Lotos,

Exaudi nos!

(L'Imitation de Notre-Dame la Lune, 1979, p.65)

Como podemos notar, este poema segue a mesma linha do anterior, traduzindo na forma o ritmo das litanias, um jogo de sentido e métrica. O título sugere uma lua sem brilho, já que está no quarto minguante. Sem luz, mesmo que irradiada pelo sol, a lua apresenta-se, neste poema, verdadeiramente estéril.

Os versos possuem quatro sílabas poéticas e as rimas utilizadas são masculinas e femininas, respectivamente, em todo o poema, sugerindo outra vez a forma do diálogo. Elas 
são soantes nos doze dísticos, número deveras singular, que nos remete ao religioso, porquanto as litanias são preces do universo litúrgico. Comprovando a ligação com a religiosidade, aparecem as palavras: Eucharistie, Fonts baptismaux, Bible, Chanaan e Mecque (esta não cristã).

Um recurso bastante utilizado pelo poeta é o da criação de palavras, juntando vocábulos a fim de produzir um efeito de sentido diverso ou dissonante, como é o caso de Vortex-Nombril e Tout-Nihil. O termo Vortex é de origem latina e estava em voga entre os decadentes. Significa turbilhão e, relacionado a Nombril (umbigo), surpreende o leitor por meio do inesperado. Talvez o poeta tenha remetido o turbilhão à forma circular do umbigo, associação original e inusitada.

Quanto a Tout-Nihil, Tout é uma das palavras mais utilizadas de maneira emblemática pelo poeta. Sugere, de acordo com Saint-Gérand (2000), uma análise panteísta e holística do universo, ligando-se ao tout, ou seja, Deus. Já Nihil, mais uma vez oriundo do latim, revela uma poesia arraigada ao pessimismo de Schopenhauer e sua teoria niilista de negativismo total.

A forma circular da lua novamente é trabalhada, ilustrada pelos termos Eucharistie, l'oeil e nombril. O astro é a eucaristia (alimento) da arcádia, mundo imaginário dos gregos onde tudo era felicidade, citado ironicamente, por ser julgado estéril:

\section{$[\ldots]$}

Ciel des idylles

Qu'on veut stériles,

$[\ldots]$

Os idílios (canções pastoris ligadas à Arcádia, onde viviam os pastores em perfeita comunhão com a natureza; ligação com a poesia árcade, citada no verso 2 / De l'Arcadie/) são estéreis como a lua, não há a felicidade aludida por eles. A figura da lua permite visões contrárias, um embate entre o tudo e o nada (é tudo para os que a cultuam e nada para os que 
a criticam), um verdadeiro turbilhão; é espelho e bíblia para seus seguidores. Traduz-se como passado, comparada à esfinge e à Gioconda defuntas, ironizando duplamente o astro e essas culturas. A visão dos fiéis de que ela é a terra prometida também traz uma ironia dupla, de sorte que critica o endeusamento da lua e terra prometida dos judeus, conforme a bíblia. Contudo, esta terra lunar descrita no poema não possui nada a oferecer além de escuridão e esterilidade. O que resta, então, é dizer :

\section{$[\ldots]$ Léthé, Lotos, Exaudi nos!}

Estes dois versos apresentam um jogo de palavras, aproximando o rio grego do esquecimento - Lete - com lótus, planta aquática exótica. Lotos pode, ainda, significar loto, referente a jogo de azar, produzindo efeito cômico. Este vocativo, sinal de oralidade, chama para fazer um pedido: Exaudi-nos, ou seja, Ouvi-nos, expressão de origem latina muito frequente em preces cristãs.

Visualiza-se, dessa forma, um poema fortemente relacionado à religião, para criticála, e à lua para ferir seus seguidores. Apresenta criações originais e bem humoradas, ironizando o turbilhão de visões a respeito do astro estéril e dos que a ele se ligam, afirmando o nada schopenhauriano deste culto.

Esse poema confirma a aproximação da lua com a figura do Pierrô, sobre o qual falaremos no próximo capítulo, dizendo que a lua é a fonte batismal dos brancos pierrôs:

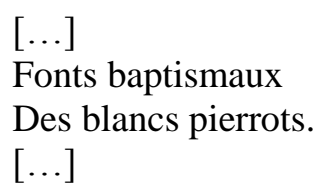

Isso nos revela que ele nasce para o culto à lua, sendo batizado para segui-la em brancura e esterilidade. 


\section{Clair de lune}

Penser qu'on vivra jamais dans cet astre, Parfois me flanque un coup dans l'épigastre.

Ah ! tout pour toi, Lune, quand tu t'avances Aux soirs d'août par les féeries du silence!

Et quand tu roules, démâtée, au large À travers les brisants noirs des nuages !

Oh ! monter, perdu, m'étancher à même Ta vasque de béatifiants baptêmes !

Astre atteint de cécité, fatal phare Des vols migrateurs des plaintifs Icares!

Eil stérile comme le suicide, Nous sommes le congrès des las, préside ;

Crâne glacé, raille les calvities De nos incurables bureaucraties ;

Ô pilule des léthargies finales, Infuse-toi dans nos durs encéphales !

Ô Diane à la chlamyde très-dorique, L'Amour cuve, prend ton carquois et pique

Ah ! d'un trait inoculant l'être aptère, Les cœurs de bonne volonté sur terre !

Astre lavé par d'inouïs déluges, Qu'un de tes chastes rayons fébrifuges,

Ce soir, pour inonder mes draps, dévie, Que je m'y lave les mains de la vie!

(L'Imitation de Notre-Dame la Lune, 1979, p.22)

O título sugere ao leitor sensações agradáveis, ambiente feérico e fantástico; mas logo nos primeiros versos, o tema se revela outro, pois deparamos com uma expressão bastante prosaica /me flanque un coup dans l'épigastre/, distante da tradição dos temas ligados ao luar na literatura à qual pertencem os simbolistas "sério-estéticos". 
Os versos são, em sua maioria, femininos, revelando-se relativos à lua e possuem dez sílabas poéticas cada, compondo, mais uma vez, doze dísticos rimados. Não obstante, os decassílabos dão um tom mais lento ao discurso poético que se constrói em função de uma invocação do eu-lírico ao astro que permanece em suas féeries du silence. O uso da segunda pessoa do singular, referindo-se à lua, e dos imperativos, exprime uma série de queixas a ela que é alvo de uma visão paródica em relação a toda a exaltação sentimental com que a poesia sempre a tratou.

Para isso, emprega-se um vocabulário que a distrata (atteint de cécité, fatal phare, oeil stérile comme le suicide, crâne glacê) e que a situa ora dentro de um universo cotidiano, ora dentro de outro, literário, mítico, imaginário, por meio do recurso tão utilizado das dissonâncias semânticas (bureaucraties / calvities) que provocam a surpresa, a obscuridade.

Da mesma forma que os poemas anteriormente analisados, este também insere a cor branca e palavras que remetem ao formato circular do astro, exemplificados por oeil e vasque. A lua é descrita alegoricamente como um navio navegando pela imensidão, nomeada au large (nome de um poema do mesmo livro), sem mastros, um farol fatal para os ícaros, portando calamidade, tragédia e esterilidade.

Recorrendo à mitologia grega, o astro é igualado à divindade Diana, com suas flechas de caçadora e, ironicamente, é apresentado como aquele que lava as paixões com seus raios castos, lembrando, novamente, os cultos simbolistas à lua.

Este poema traz consigo um tom paródico influenciado pela musicalidade das cantigas populares francesas do século XIX, possivelmente parte da infância e adolescência do poeta. Podemos encontrar semelhanças entre "Clair de Lune" e a canção "Au Clair de La Lune", de autor desconhecido, tanto no ritmo quanto em vocabulário: 


\section{Au clair de la lune}

Au clair de la lune, mon ami Pierrot

Prête-moi ta plume, pour écrire un mot.

Ma chandelle est morte, je n'ai plus de feu.

Ouvre-moi ta porte, pour l'amour de Dieu.

Au clair de la lune, Pierrot répondit :

_ Je n'ai pas de plume, je suis dans mon lit.

Va chez la voisine, je crois qu'elle y est

Car dans sa cuisine, on bat le briquet.

Au clair de la lune, l'aimable lubin

Frappe chez la brune, elle répond soudain

_ Qui frappe de la sorte ?, il dit à son tour

- Ouvrez votre porte pour le Dieu d'Amour.

Au clair de la lune, on n'y voit qu'un peu

On chercha la plume, on chercha le feu

En cherchant d'la sorte je n'sais c'qu'on trouva

Mais je sais qu'la porte sur eux se ferma.

A música, que possui várias versões modificadas, é construída por 16 decassílabos masculinos, pois estes descrevem um diálogo com o Pierrô, sob a luz da lua. Visualiza-se pontos de encontro com o poema de Laforgue no uso de termos ligados à luz, ao fogo, ao amor e à porta fechada da cantiga, a qual poderia ser ligada ao último verso da composição laforguiana : /Que je m'y lave les mains de la vie!/

Além da proximidade com a canção, identificamos influências verlainianas e de seu "Clair de Lune":

\section{Clair de lune}

Votre âme est un paysage choisi

Que vont charmant masques et bergamasques

Jouant du luth et dansant et quasi

Tristes sous leurs déguisements fantasques.

Tout en chantant sur le mode mineur

L'amour vainqueur et la vie opportune

Ils n'ont pas l'air de croire à leur bonheur

Et leur chanson se mêle au clair de lune,

Au calme clair de lune triste et beau,

Qui fait rêver les oiseaux dans les arbres

Et sangloter d'extase les jets d'eau,

Les grands jets d'eau sveltes parmi les marbres. 
O poema de Verlaine possui três quartetos, totalizando doze versos decassílabos, números semelhantes aos de Laforgue. Verlaine descreve um luar triste, porém bom e estimulante, como afirma Balakian (2000, p. 53):

Ao sugerir a qualidade característica da pessoa amada, Verlaine diz que a alma dela é uma paisagem onde alguém canta coisas alegres em tons menores. Também descobriu, no mesmo volume, que a meia-luz é mais rica de força sugestiva e como estimulante á imaginação do que a brilhante luz solar, e que palavras que implicam emoção são mais poderosas ao comunicar a emoção do que as palavras que as designam.

O luar de Laforgue é estéril e irônico, criticando a força provinda do luar verlainiano e buscando na paródia recursos para ironizá-lo. Se a lua é alvo de inúmeras créticas desferidas, assim também acontece com o luar, oriundo do astro elucidado, e com as pessoas que adoram e se deleitam sob os raios daquela que tanto os românticos e simbolistas da corrente "sérioestética" exaltaram.

O próximo poema a ser abordado está contido no livro L'Imitation de Notre-Dame La Lune, 1979, p.45 e arquiteta um diálogo interior do eu-lírico, levantando questões de natureza filosófica e existenciais. Trará marcas próprias do Simbolismo, como o uso de letras maiúsculas em várias palavras, além do pessimismo decadente e da inserção do nada, frutos da influência schopenhauriana: 


\section{Dialogue avant le lever de la lune}

-Je veux bien vivre; mais vraiment, L'Idéal est trop élastique!

-C'est l'Idéal, son nom l'implique, Hors son non-sens, le verbe ment.

-Mais, tout est conteste; les livres S'accouchent, s'entretuent sans lois !

-Certes ! L'Absolu perd ses droits, Là, où le Vrai consiste à vivre.

-Et, si j'amène pavillon

Et repasse au Néant ma charge ?

-L'Infini, qui souffle du large, Dit: «pas de bêtises, voyons ! »

-Ces chantiers du Possible ululent À l'Inconcevable, pourtant !

-Un degré, comme il en est tant Entre l'aube et le crépuscule.

-Être actuel, est-ce, du moins, Être adéquat à Quelque Chose ?

-Conséquemment, comme la rose Est nécessaire à ses besoins.

-Façon de dire peu commune Que Tout est cercles vicieux?

-Vicieux, mais Tout! -J'aime mieux Donc m'en aller selon la Lune.

Este poema demonstra o coerente fazer poético de Laforgue, nada escrevendo ao acaso, ligando a temática à estrutura. Novamente um diálogo, como é possível perceber por meio dos doze dísticos rimados e metricamente construídos com oito sílabas poéticas por verso, contendo rimas duais, abraçadas e intercaladas entre masculinas e femininas, além dos travessões. A quebra ocorre na quarta ou quinta sílabas, permitindo um ritmo rápido e fluente, como em um diálogo, o qual é interior, relativo a questões da existência humana, no caso o Ser e o Ideal. Este diálogo é feito entre a aurora e o crepúsculo, às claras, como mostra 
o título Dialogue avant le lever de la lune. A argumentação seguirá como um embate entre o ser e o ideal, mas não tomará posição em defesa de nenhum deles.

O termo Idéal pode significar aquilo que existe nas ideias e na imaginação, bem como aquilo que reúne todas as perfeições. Seu emprego, segundo Saint-Gérand (2000), é emblemático nos poemas de Laforgue, sendo tão significativo quanto o pessimismo filosófico adquirido. Somando às palavras emblemáticas, encontramos dupla referência ao Tout, sempre iniciado com maiúscula, confirmando sua importância no poema.

O texto segue afirmando que a vida precisa ser vivida com verdade, mas tudo é contestação, como o verbo que mente e os livros sem leis.

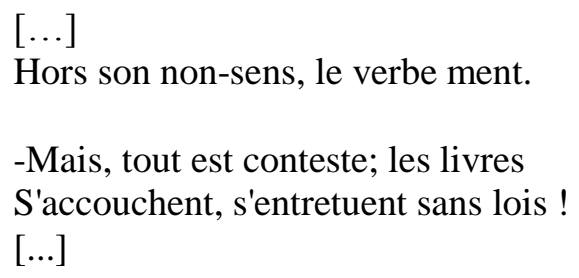

Mas o viver opõe-se ao Ideal, ao Possível e ao Inconcebível, todos com as iniciais maiúsculas, como se pode encontrar em muitos poemas simbolistas. O Ideal, por sua vez, opõe-se ao Ser, o que é sugerido pela gradação entre ambos, ocasionada pelas modulações da argumentação levando ao diálogo: mais, pourtant, mais, donc.

A cada sete dias a lua muda de fase e o eu-lírico o faz com ela, seguindo o estratagema do astro. Até o sexto dístico, a argumentação era em favor do Ser, terminando com uma chamada de atenção para o que virá; a partir do sétimo, será em favor do Ideal, iniciando-se com o pourtant, adversativo. No sétimo dístico figura o verbo ululer, que traduz o canto das corujas. A busca por um caminho a seguir vem como um lamento noturno, representado, no poema, pelo barulho agourento da ave. A tentativa de conciliação entre Ser e Ideal visando trilhar novos caminhos não se efetua; mas, ao tentar alcançá-la, o eu-lírico cai em um círculo vicioso do qual quer escapar. 


\section{Au large}

Comme la nuit est lointainement pleine

De silencieuse infinité claire!

Pas le moindre écho des gens de la terre,

Sous la Lune méditerranéenne !

Voilà le Néant dans sa pâle gangue,

Voilà notre Hostie et sa Sainte-Table,

Le seul bras d'ami par l'Inconnaissable,

Le seul mot solvable en nos folles langues !

Au-delà des cris choisis des époques,

Au-delà des sens, des larmes, des vierges,

Voilà quel astre indiscutable émerge,

Voilà l'immortel et seul soliloque !

Et toi, là-bas, pot-au-feu, pauvre Terre !

Avec tes essais de mettre en rubriques

Tes reflets perdus du Grand Dynamique,

Tu fais un métier ah ! bien sédentaire !

(L'Imitation de Notre-Dame La Lune, 1979, p.21)

Au large, expressão utilizada em alguns dos poemas de Laforgue para nomear a imensidão onde habita a lua. Estes quatro quartetos compostos por decassílabos femininos anunciam que o astro estéril será, mais uma vez, o centro das considerações.

Existem, no poema, vocábulos fazendo alusão à religiosidade, possibilitando a comparação da lua com uma divindade: Hostie, Sainte Table. As pessoas da terra clamam este astro, cultuando-o como a um deus que vive na imensidão:

Comme la nuit est lointainement pleine

De silencieuse infinité claire!

Pas le moindre écho des gens de la terre,

Sous la Lune méditerranéenne !

$[\ldots]$

A lua é descrita com esterilidade, pois está reduzida ao nada, sem apresentar brilho, nem valor, uma possível influência da filosofia schopenhauriana. Ela emerge no céu, semelhante a uma hóstia sobre o altar, trabalho sedentário na opinião do eu-írico. Dessa forma, o sujeito narrativo do poema critica os que cultuam a lua, primeiramente por elevá-la à 
condição divina e, em segundo lugar, por cultuarem o nada. Ao mesmo tempo, é construída uma crítica à própria religião, na medida em que se inserem elementos do universo cristão em meio à afirmação do nada lunar. Este recurso da ironia dupla foi trabalhado e aperfeiçoado por Laforgue que o empregou em diversos de seus poemas. 


\section{Laforgue e o Pierrô Lunar}

O poeta Jules Laforgue deixou, após sua morte, um considerável número de poemas construídos com muito spleen, marcas de oralidade, de ironia e de humor. Dentre as temáticas utilizadas pelo escritor estão os domingos, os lamentos, as pequenas misérias, as litanias, a lua e, ligado a esta última, o Pierrô.

Ele é um personagem tradicional da Commedia dell'Arte, forma de teatro popular improvisado surgido na Itália, no século XV, e desenvolvido na França, no século XVI. Este se opõe ao teatro erudito e cria uma nova linguagem teatral; as peças, apresentadas em praças e ruas, trazem ao público o riso, a comicidade, a ridicularização e diálogos repletos de ironia e humor, fato que vem ao encontro da poética de Laforgue. O Pierrô é uma variação francesa do Pedrolino italiano; sua caracterização é semelhante à de um palhaço, porém triste, pálido, normalmente com uma lágrima desenhada no rosto; usa roupas largas, ora brancas, ora dividindo espaço com o preto. É um ser ingênuo, bobo, facilmente enganado, distante da realidade, representado às vezes como um lunático. Apaixonado pela Colombina, tem o coração partido por ter sido trocado pelo Arlequim.

A figura do Pierrô aparece em diversos poemas de Laforgue, sobretudo no livro L'Imitation de Notre-Dame la Lune, sugerindo uma ligação entre o personagem e a lua. Com efeito, após a leitura atenta destes versos, encontra-se um Pierrô lunar, não simplesmente por referir-se à lua, mas por, com seu riso tristonho de Gioconda, zombar daqueles que cultuam o astro estéril.

Além de poemas sobre o personagem, Laforgue também escreveu uma peça na qual retratava o Pierrô, intitulada Pierrot fumiste. Nela, o poeta descreve uma figura que está em suas núpcias com a Colombina, mas os três atos são, sobretudo, humorísticos, traço cômico este que será visualizado com frequência nos poemas tecidos por meio da iserção deste personagem. 
Segundo Rezende (1997, p.29), o Pierrô liga-se a embates envolvendo amor e mágoa, produzindo monólogos interiores que levam o sujeito narrativo às próprias lembranças, um relato compulsivo do choque entre idealidade e realidade. E continua:

\begin{abstract}
Laforgue persegue então uma "dicção coloquial", um longo soluço expressivo da miséria anímica do narrador. Para tanto, recorre a um metro flexível e um léxico pouco marcado pela "elevação poética". [...] Laforgue vai ousar mais no grau de liberdade prosódica, mesmo porque seu narrador magoado precisa exprimir estados d'alma passavelmente mais complexos do que os de um bichinho de fábula. A mesma busca de uma dicção íntima, "em tom menor", reduz o número de palavras raras e referências míticosimbólicas à devida proporção, sem eliminá-las (nem seria uma preocupação do poeta; além do lado dândico de seu pierrô enluarado, para o público da época suas alusões esparsas eram perfeitamente acessíveis; trata-se de, por assim dizer, de elementos de cultura popular e/ou folhetinesca).
\end{abstract}

Nos vários poemas elaborados a partir desta temática, o personagem é descrito como se estivesse embriagado, sob efeito de ópio, ou com ar de portador de hidrocefalia /Un air d’hydrocéfale asperge/, doença caracterizada pelo acúmulo de líquido na região cerebral, deixando o semblante da pessoa abobalhado, ou seja, com a aparência de estar longe da realidade, o que pode ser comprovado no primeiro poema da sequência que trata do Pierrô. Este aparece como um ser amargurado, pessimista e enganável, o que sugere a interferência das filosofias de Schopenhauer e Hartmann, niilistas.

O que será observado nestes poemas é que eles diferem dos construídos em torno da lua, no que diz respeito à estrutura e ao tom. Estruturalmente, as composições sobre o Pierrô possuem fórmulas diferentes entre si, uns com versos mais curtos, outros mais longos, apresentando enjambements e marcas gráficas dissonantes como parênteses e itálicos. Quanto ao tom, os diálogos aqui trabalhados são interiores, repletos de discussões mais existenciais, diferente das críticas paródicas encontradas nos poemas lunares. 


\section{Pierrots}

C'est, sur un cou qui, raide, émerge

D'une fraise empesée idem,

Une face imberbe au cold-cream,

Un air d'hydrocéphale asperge.

Les yeux sont noyés de l'opium

De l'indulgence universelle,

La bouche clownesque ensorcèle

Comme un singulier géranium.

Bouche qui va du trou sans bonde

Glacialement désopilé,

Au transcendantal en-allé

Du souris vain de la Joconde.

Campant leur cône enfariné

Sur le noir serre-tête en soie,

Ils font rire leur patte d'oie

Et froncent en trèfle leur nez.

Ils ont comme chaton de bague

Le scarabée égyptien,

À leur boutonnière fait bien

Le pissenlit des terrains vagues.

Ils vont, se sustentant d'azur!

Et parfois aussi de légumes,

De riz plus blanc que leur costume,

De mandarines et d'œufs durs.

Ils sont de la secte du Blême,

Ils n'ont rien à voir avec Dieu,

Et sifflent: « tout est pour le mieux

«Dans la meilleur' des mi-carême !»

(L'Imitation de Notre-Dame la Lune, 1979, p. 28)

Observa-se, no início do poema, a visão de um Pierrô abobalhado, com o pescoço saindo da roupa típica, o rosto branco e a expressão aérea, como descrito no primeiro quarteto: 
C'est, sur un cou qui, raide, émerge

D'une fraise empesée idem,

Une face imberbe au cold-cream,

Un air d'hydrocéphale asperge.

$[\ldots]$

Em seguida, a descrição continua, mas fazendo alusão ao ópio, planta utilizada como narcótico que, após a euforia inicial, provoca sono onírico, revelado, então, pelos olhos do personagem que não mudam de expressão, da mesma forma que sua boca sem profundidade:

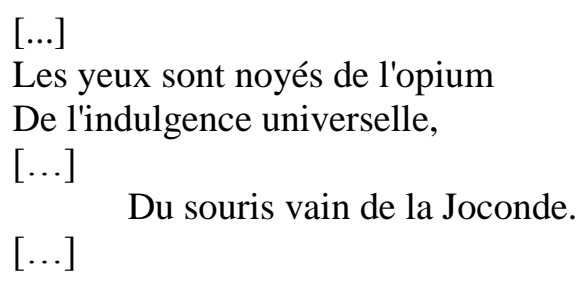

O poema é constituído de sete quartetos, todos com oito sílabas poéticas em cada verso, com rimas interpoladas, várias ricas, divididas entre masculinas e femininas, divisão comum nos poemas do escritor francês. A métrica trabalhada reforça a crítica, ironizando a preocupação estética e marcando um ritmo de monotonia que se encaixa à temática do "Pierrô-lunático".

O eu-lírico enxerga os seguidores da lua como lunáticos e distraídos, semelhantes à figura deste Pierrô. Este possui ainda um sorriso estéril, comparado ao da Monalisa, de Leonardo da Vinci, característica que o liga à temática lunar devido à esterilidade dessa expressão. Assim como a lua descrita em L'Imitation de Notre-Dame la Lune, o sorriso do Pierrô também é estéril, souris vain, completando a ironia trabalhada ao longo das páginas do livro. Além disso, o fato de não se conseguir interpretar o significado do sorriso, confere-lhe ambiguidade: pode ser favorável ao culto à lua ou irônico; pode exaltar a pintura de Leonardo da Vinci, elogiando o enigma que permanece mesmo com o passar dos séculos, ou desmitificá-la através da esterilidade do semblante do Pierrô lunar, condenando o culto ao que se considerava belo, ao antigo transformado em mito. 
O poema descreve o Pierrô abobalhado como um ser sem expressão facial, possuidor de doentia palidez, Blême. A ironia é expressa pela comicidade das marcas faciais como o nariz em forma de trevo /Et froncent en trèfle leur nez/ e os pés-de-galinhas, patte d'oie. Como explicar estas rugas em um rosto estático?

Há também ironia e humor no momento em que é revelado que o personagem vive do azur, ou seja, vive nas nuvens, com um pouco de legumes ou arroz às vezes, situação comparada à quaresma cristã, na qual existe a prática do jejum e da oração. Um confronto com os ideais literários e também cristãos, com o viver de postulados. A surpresa da junção de termo poético (azur) e prosaicos (legumes e arroz) produz dissonância.

Em se tratando do termo azur, Balakian (2000, p. 65) tece considerações a seu respeito, ligando-o aos simbolistas e, sobretudo, a Mallarmé; possivelmente, mais um sinal de ironia ao movimento por parte de Jules Laforgue. Azur traduz o infinito, a imensidão, misturando o azul ao céu, sendo empregado, portanto, com sentido poético nas obras dos grandes simbolistas da corrente "sério-estética". Contudo, o poeta "coloquial-irônico" faz uso deste termo em meio ao cômico e ao prosaísmo, criticando o movimento simbolista e o academismo poético levado ao extremo por grande parte dos autores ligados a este movimento.

Azur, uma palavra intraduzível em inglês que combina os significados de "azul" e "céu" e sua impenetrabilidade misteriosa, se tornará uma das convenções literárias do simbolismo; quando o poeta latino-americano Rubén Darío intitula seu importante primeiro volume de versos $A z u l$, a palavra espanhola adquire o significado metafísico que Mallarmé dera a sua equivalente francesa. Depois disso, a palavra se torna parte do código simbolista, e tão linguisticamente universal quão conceptualmente complexa. 
Le cœur blanc tatoué

De sentences lunaires,

Ils ont: « Faut mourir, frères ! »

Pour mot-d'ordre-Évohé.

Quand trépasse une vierge,

Ils suivent son convoi,

Tenant leur cou tout droit

Comme on porte un beau cierge.

Rôle très-fatigant,

D'autant qu'ils n'ont personne

Chez eux, qui les frictionne

D'un conjugal onguent.

Ces dandys de la lune

S'imposent, en effet,

De chanter «s'il vous plaît ?»

De la blonde à la brune.

Car c'est des gens blasés;

Et s'ils vous semblent dupes,

Çà et là, de la Jupe,

Lange à cicatriser,

Croyez qu'ils font la bête

Afin d'avoir des seins,

Pis-aller de coussins

A leurs savantes têtes.

Écarquillant le cou

Et feignant de comprendre

De travers, la voix tendre,

Mais les yeux si filous!

-D'ailleurs, de mœurs très fines,

Et toujours fort corrects,

(École des cromlechs

Et des tuyaux d'usines).

(L'Imitation de Notre-Dame La Lune, 1979, p.29)

Os poemas envolvendo o Pierrô contêm ritmo rápido apresentando rimas, o que favorece o aparecimento do humor, se pensarmos que a rima, além de ser usada na lírica, é 
um recurso pródigo dos humoristas. No número II, os oito quartetos são compostos por versos de seis sílabas poéticas, as quais possuem rimas abraçadas intercalando as masculinas e as femininas, estrutura marcante nos poemas de Laforgue, pois parodia a preocupação parnasiana e, em menor escala, simbolista, com a métrica. O poeta, ao mesmo tempo em que é irônico, trabalhando a métrica, aplica recursos da linguagem oral, sem precisar do verso livre para isso, construindo, dessa forma, versos humorados e críticos, além de inovadores.

Logo no início do poema visualizamos a ligação do Pierrô com a lua, ambos figurando a ironia pretendida. A relação entre eles revela-se estreita, uma vez que o coração do personagem permanece branco e tatuado de sentenças lunares:

Le cœur blanc tatoué

De sentences lunaires,

$[\ldots]$

O poema possui vocabulário mais voltado para o popular e prosaico do que para o poético, e expressões que, por serem irônicas, aproximam-se do cômico, atribuindo aos versos um ritmo próximo do cotidiano e, por essa razão, tocado pela oralidade: convoi, cierge, onguent, dupes, jupe, lange filous, tuyaux d'usine. Cierge (vela branca e fina) desempenha, ainda, uma função alegórica visando a comicidade, pois, além de confirmar a brancura do Pierrô, é comparada àquele que, atento aos menores detalhes, como uma vela erguida, segue as mulheres que deseja de maneira dissimulada:

Quand trépasse une vierge,

Ils suivent son convoi,

Tenant leur cou tout droit

Comme on porte un beau cierge.

Os pierrôs são classificados, neste segmento, como dandys da lua, meio sonâmbulos, mas falsos desentendidos, pois se mostram ingênuos e indiferentes a fim de conquistar as mulheres, das loiras às morenas. 
Ces dandys de la lune

S'imposent, en effet,

De chanter «s'il vous plaît ?»

De la blonde à la brune.

Apresentam-se frágeis, precisando de cuidados, comparados a crianças que ainda não saíram das fraldas, o que nos é sugerido pelo termo Lange. O intento de conseguir estar próximo às saias, ou seja, às mulheres, está expresso pela palavra Jupe, iniciada com maiúscula:

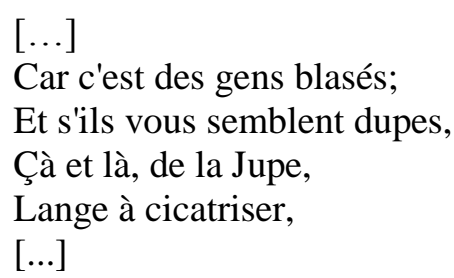

O tom de ironia surge mais fortemente quando somos alertados de que, se abrirmos bem os olhos, não nos deixaremos enganar pela suavidade da voz desses malandros:

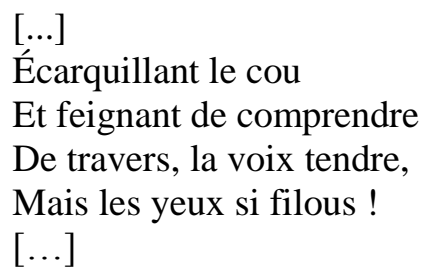

Comme ils vont molester, la nuit, Au profond des parcs, les statues, Mais n'offrant qu'aux moins dévêtues Leur bras et tout ce qui s'ensuit,

En tête à tête avec la femme Ils ont toujours l'air d'être un tiers, Confondent demain avec hier, Et demandent Rien avec âme!

Jurent « je t'aime ! » l'air là-bas, D'une voix sans timbre, en extase, Et concluent aux plus folles phrases Par des: «mon Dieu, n' insistons pas ? »

Jusqu'à ce qu'ivre, Elle s'oublie, Prise d'on ne sait quel besoin De lune? Dans leurs bras, fort loin 
Des convenances établies.

(L'Imitation de Notre-Dame La Lune, 1979, p.30)

O terceiro poema desta sequência corrobora a imagem embriagada que o eu-lírico apresenta do Pierrô, somada à dissimulação visando conquistar as mulheres. Os quatro quartetos de oito sílabas poéticas por verso seguem o mesmo esquema rítmico e rimado de I e II, com rapidez e prosaísmo. O Pierrô descrito é um típico galanteador, jurando falso amor em busca dos prazeres carnais, proferindo elogios sem olhar nos olhos da amada, nem demonstrando sinceridade em sua voz:

Jurent « je t'aime ! » l'air là-bas,

D'une voix sans timbre, en extase,

$[\ldots]$

O eu-lírico deixa clara uma crítica ao culto lunar, alegando não entender qual é essa necessidade de alguns pelo astro. A mulher que figura no poema, envolta pela lua, esquece as convenções e cede ao Pierrô embriagado:

Jusqu'à ce qu'ivre, Elle s'oublie,

Prise d'on ne sait quel besoin

De lune ? Dans leurs bras, fort loin

Des convenances établies.

\section{IV}

Maquillés d'abandon, les manches

En saule, ils leur font des serments,

Pour être vrais trop véhéments !

Puis tumultuent en gigues blanches,

Beuglant: Ange! Tu m'as compris,

A la vie, à la mort ! -et songent :

Ah ! Passer là-dessus l'éponge ! ...

Et c'est pas chez eux parti pris,

Hélas ! mais l'idée de la femme

Se prenant au sérieux encor

Dans ce siècle, voilà, les tord

D'un rire aux déchirantes gammes ! 
Ne leur jetez pas la pierre, $\hat{o}$

Vous qu'affecte une jarretière !

Allez, ne jetez pas la pierre

aux blancs parias, aux purs pierrots !

(L'Imitation de Notre-Dame La Lune, 1979, p.31)

Neste poema, o qual segue o mesmo esquema rítmico do anterior, a figura do Pierrô está alegorizada pelo chorão (saule), árvore de galhos caídos como as mangas da vestimenta do personagem. Inicia-se com uma abstração criada a partir de um complemento nominal construído pela junção de um termo concreto e outro abstrato: /Maquillés d'abandon/, referindo-se às mangas de chorão. Os versos jogam com a cor branca das pernas do Pierrô, humor que se mantém ao comparar sua voz a berros de carneiro (beuglant).

O Pierrô quer estar com a amada, neste poema, pedindo a ela que apague o que passou e se prenda a ele. Contudo, o eu-lírico tece sua ironia afirmando que essa atitude feminina, naquele século, provocaria risos em larga escala. Por conseguinte, suplica para que não apedrejem o pobre Pierrô, aqui tido como pária e puro, aliteração que provoca riso irônico, já que a pureza está bem distante das considerações tecidas até então sobre o personagem abobalhado.

Aparece, nestes versos, como intertexto, a Ordem da Jarreteira, mostrando as maliciosas intenções do Pierrô. Esta ordem militar foi implantada por Eduardo III, na Inglaterra. Na lenda associada à sua criação, Eduardo III estava dançando com a Condessa de Salisbury numa grande festa da corte, quando ela deixou sua jarreteira cair. A condessa amarrou-a novamente na perna, mas foi alvo de sorrisos e murmúrios dos que estavam presentes no baile. Vendo isso, o rei exclamou profundamente incomodado: «Honni soit qui mal y pense» ("envergonhe-se quem nisto vê malícia"), frase que se tornou o lema da ordem.

$\mathrm{Na}$ última estrofe, é possível visualizar um intertexto com o universo religiosocristão, por meio do uso de uma expressão relacionada ao evangelho bíblico que relata a situação da mulher adúltera prestes a ser apedrejada. Jesus diz aos que estavam no local que, 
se não tivessem pecado, atirassem a pedra, fala que os levou a se retirarem. Esta conhecida frase é utilizada por Laforgue em defesa de seu Pierrô amargurado, comparado aos excluídos da sociedade, os quais eram também defendidos por Jesus, e chamados de puros, termo que encerra este poema laforguiano:

$[\ldots]$

Ne leur jetez pas la pierre, ô

Vous qu'affecte une jarretière !

Allez, ne jetez pas la pierre

aux blancs parias, aux purs pierrots !

\section{V}

Blancs enfants de chœur de la lune,

Et lunologues éminents,

Leur Église ouvre à tout venant,

Claire d'ailleurs comme pas une.

Ils disent, d'un œil faisandé,

Les manches très-sacerdotales,

Que ce bas monde de scandale

N'est qu'un des mille coups de dé

Du jeu que l'Idée et l'Amour,

Afin sans doute de connaître

Aussi leur propre raison d'être,

Ont jugé bon de mettre au jour.

Que nul d'ailleurs ne vaut le nôtre,

Qu'il faut pas le traiter d'hôtel

Garni vers un plus immortel,

Car nous sommes faits l'un pour l'autre;

Qu'enfin, et rien de moins subtil,

Ces gratuites antinomies

$\mathrm{Au}$ fond ne nous regardant mie,

L'art de tout est l'Ainsi soit-il;

Et que, chers frères, le beau rôle

Est de vivre de but en blanc

Et, dût-on se battre les flancs,

De hausser à tout les épaules.

(L'Imitation de Notre-Dame La Lune, 1979, p.31) 
Este poema acompanha a métrica do anterior, porém não mais joga com termos populares, e sim com os do universo religioso, produzindo ironia com relação à lua e à religiosidade. O eu-lírico insere a lua como uma divindade, possuindo igreja e doutrina, além de diversos seguidores. Mais uma vez o Pierrô está associado à atmosfera enluarada, da mesma forma que o poema denota uma crítica ao culto lunar. Os seguidores do astro estéril são os pierrôs, figuras ligadas novamente à cor branca e cujas vestimentas são comparadas, dessa vez, às sacerdotais; /Les manches três-sacerdotales/.

O mundo em que vivemos é ironicamente intitulado bas-monde e, diferentemente do ideal, onde habita a lua, é repleto de escândalos e de acasos, aludindo a Mallarmé e seu Un coup de dés jamais n'abolira le hasard.

As estrofes mostram uma sucessão de falas atribuídas aos pierrôs de olhos macerados /Ils disent, d'un oeil faisandé,/ declarando que eles e a lua foram feitos um para o outro. O astro é, assim como no poema "Litanies des derniers quartiers de la Lune" , intitulado l’hôtel garni; no entanto, desta vez não está ornamentado no infinito, e sim para o imortal.

Para concluir o poema, é feita uma crítica à arte em geral utilizando elementos que se relacionam com o religioso, constituindo uma dupla ironia, recurso próprio de Laforgue como já explicitado anteriormente. O eu-lírico revela que a arte de tudo é concordar com o que foi estabelecido, levantando os ombros em sinal de seguimento sem discordância, proferindo sempre um amém:

[...]

L'art de tout est l'Ainsi soit-il;

Et que, chers frères, le beau rôle

Est de vivre de but en blanc

Et, dût-on se battre les flancs,

De hausser à tout les épaules. 


\section{Pierrots}

(On a des principes.)

Elle disait, de son air vain fondamental :

«Je t'aime pour toi seul! »-oh ! Là, là, grêle histoire;

Oui, comme l'art ! Du calme, ô salaire illusoire

Du capitaliste l'Idéal!

Elle faisait: « J'attends, me voici, je sais pas »...

Le regard pris de ces larges candeurs des lunes;

-Oh ! Là, là, ce n'est pas peut-être pour des prunes,

Qu'on a fait ses classes ici-bas ?

Mais voici qu'un beau soir, infortunée à point,

Elle meurt ! -Oh ! Là, là ; bon, changement de thème !

On sait que tu dois ressusciter le troisième

Jour, sinon en personne, du moins

Dans l'odeur, les verdures, les eaux des beaux mois!

Et tu iras, levant encor bien plus de dupes

Vers le Zaïmph de la Joconde, vers la Jupe !

Il se pourra même que j'en sois.

(L'Imitation de Notre-Dame La Lune, 1979, p.33)

Este poema traça uma métrica diferenciada dos demais, utilizando versos dodecassílabos e o de nove sílabas em uma mesma estrofe. O ritmo é mais alongado, entrecortado por vários enjambements e, em consequência, mais prosaico, apesar de manter a rima abraçada em tom de diálogo (intercalando masculinas e femininas). A oralidade revelase por meio do uso do pronome on e da inserção de travessões, reticências, interjeições, frases interrogativas ou expressões da linguagem popular: -Oh! là, là; Du calme.

Como já visto em outros poemas, termos emblemáticos figuram nestes versos (Idéal) juntamente com a presença de elementos greco-romanos representados aqui pela Gioconda, todos iniciados por maiúsculas. 
$\mathrm{Na}$ última estrofe, confirma-se a visão de um Pierrô que parece tolo e ingênuo em busca de estar junto às mulheres. $\mathrm{O}$ vocabulário empregado é dissonante, misturando termos de campos semânticos distintos, aproximando odores, verduras, águas, tolos e saias:

Dans l'odeur, les verdures, les eaux des beaux mois !

Et tu iras, levant encor bien plus de dupes

Vers le Zaïmph de la Joconde, vers la Jupe !

Il se pourra même que j'en sois.

\section{Pierrots}

(Scène courte, mais typique.)

Il me faut, vos yeux ! Dès que je perds leur étoile, Le mal des calmes plats s'engouffre dans ma voile, Le frisson du Vae soli ! gargouille en mes moelles...

Vous auriez dû me voir après cette querelle !

J'errais dans l'agitation la plus cruelle,

Criant aux murs: Mon dieu ! mon dieu ! Que dira-t-elle ?

Mais aussi, vrai, vous me blessâtes aux antennes

De l'âme, avec les mensonges de votre traîne.

Et votre tas de complications mondaines.

Je voyais que vos yeux me lançaient sur des pistes, Je songeais : oui, divins, ces yeux ! mais rien n'existe Derrière! Son âme est affaire d'oculiste.

Moi, je suis laminé d'esthétiques loyales !

Je hais les trémolos, les phrases nationales ;

Bref, le violet gros deuil est ma couleur locale.

Je ne suis point « ce gaillard-là ! » ni Le Superbe !

Mais mon âme, qu'un cri un peu cru exacerbe,

Est au fond distinguée et franche comme une herbe.

J'ai des nerfs encor sensibles au son des cloches, Et je vais en plein air sans peur et sans reproche, Sans jamais me sourire en un miroir de poche.

C'est vrai, j'ai bien roulé ! J'ai râlé dans des gîtes Peu vous; mais, n'en ai-je pas plus de mérite À en avoir sauvé la foi en vos yeux ? Dites....

-Allons, faisons la paix, venez, que je vous berce, Enfant. Eh bien?

-C'est que, votre pardon me verse Un mélange (confus) d'impressions... diverses... 
Esta composição, diferentementes das outras, revela um tom mais confessional. Segue a linha prosaica da última, apresentando nove tercetos de versos dodecassílabos, sendo que o último possui uma quebra no ritmo, também devido a enjambements, a fim de inserir uma fala, já que se trata de um poema permeado pela oralidade traduzida em palavras e expressões: Mon dieu! Eh bien?

Estas linhas decrevem uma cena típica de galanteio e querela amorosa, em que elogios românticos são tecidos à pessoa amada. Contudo, o eu-lírico alega ter sido enganado e, nesse contexto, há uma quebra de expectativa no leitor, pois o vocabulário se torna irônico, quando este eu-lírico, surpreendido pelo engano, conclui a falta de profundidade do olhar feminino:

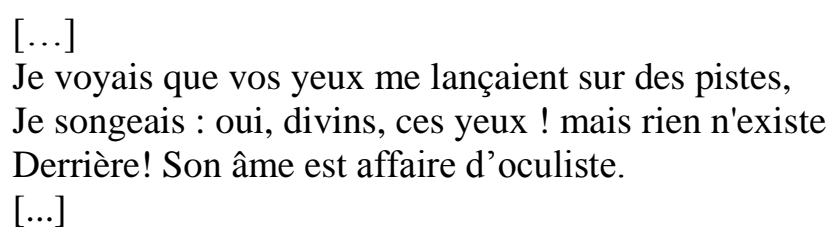

É possível visualizar um monólogo interior do Pierrô, desiludido e perguntando-se sobre a verdade dos sentimentos da pessoa desejada. Estas interrogações favorecem a oralidade, mesmo em versos rimados e metricamente elaborados, sonoridade oriunda das cantigas populares. A influência do popular pode ser encontrada na expressão tão conhecida de que os olhos transparecem a alma, a qual é ironizada pela necessidade de um oculista. Como o centro do poema é a figura da mulher que (não) se mostra pelo olhar, ele é todo construído com rimas exclusivamente femininas. 


\section{Considerações finais}

Após percorrer parte da obra poética de Jules Laforgue, podem-se perceber algumas constantes que a marcam e que prenunciam as direções que a poesia moderna tomará no século XX. Essas constantes são, sobretudo: ironia, muitas vezes dupla, paródia, a procura por formas orais, a criação de neologismos e oxímoros, a construção da dissonância e a intertextualidade, além do emprego de um vocabulário etimológico, estrangeiro ou arcaico, características que se relacionam de maneira original e inovadora, revolucionando assim a maneira de fazer poesia.

Foi possível notar que o poeta francês tem pontos de encontro com os dois movimentos literários abordados neste trabalho: Simbolismo e Decadentismo. Todavia, sua produção foi tão própria e particular que podemos dizer que a poética de Laforgue toca os movimentos, na medida em que aborda questões inerentes a suas temáticas, como a trangressão e o pessimismo, somado à apropriação de características como o uso de maiúsculas, da cor branca e da métrica simbolistas; em contrapartida, sua escrita é original e inovadora, não por criar novos recursos para a elaboração de seus poemas, mas por justamente utilizar ferramentas já existentes, inclusive nesses dois movimentos, com o intuito de escrever uma nova poesia.

Além disso, como representante da corrente "coloquial-irônica" simbolista, Jules Laforgue insere em meio à métrica elaborada, termos da linguagem popular, cotidiana e/ou coloquial, o que favorece a construção da ironia, a qual é recorrente e duplamente utilizada: enquanto o poeta se serve de figuras que possam ironizar determinado tema ou personagem, também ironiza esta figura que foi inserida para provocar crítica. O trabalho com este recurso acontece em grande parte dos poemas estudados e provoca um interessante efeito de sentido, somado à dissonância, à paródia, ao humor, à sátira e à oralidade. 
Com relação à oralidade, entendemos que ela, juntamente com a ironia, traz complexidade aos escritos laforguianos. Ela ocorre por meio do uso de vocábulos do cotidiano, de marcas gráficas sugerindo elisões, de gírias e termos prosaicos, do uso de várias vozes que dialogam, ou mesmo do monólogo, das cantigas de cunho popular relacionadas à tradição oral e, ainda, da inserção de nomes mitológicos. Essa intertextualidade, no que diz respeito ao mundo clássico, é completada também com a citação de obras da preferência dos simbolistas, bem como de autores consagrados nesse âmbito.

Outra importante consideração a ser feita é sobre a vida do poeta. Muitos fatos apresentados mostraram-se imprescindíveis para a leitura e para a análise dos poemas laforguianos. O ennui por ele experienciado desde a infância, a perda de seus familiares, a permanência na Alemanha, o contato com grandes artistas e obras de arte, entre outros, influenciaram diretamente a maneira de pensar e de escrever de Laforgue, o que pode ser comprovado durante o estudo dos poemas aqui apresentados.

Em se tratando dos poemas lunares e os ligados ao Pierrô, visualizamos duas distintas formas de fazer poesia. Nas composições cuja temática é a figura da lua, encontramos uma aproximação entre a métrica e o conteúdo dos poemas, os quais são rimados, intercalando rimas femininas e masculinas, sempre em tom de diálogo, seja este com o astro ou interior, discorrendo sobre questões como o ideal, o qual é ansiado pelos poetas. Este conjunto de poemas é repleto de intertextos míticos, exemplificados aqui por Diana e Prometeu; religiosos, como é o caso de Eva, Grand-Pardon, Eucaristia, etc; e literários, a exemplo de Hamlet e Salammbô, demandando, assim, uma análise atenta no que diz respeito ao vocabulário e ao sentido que tais nomes citados podem ganhar quando incluídos em meio à temática da lua. Também foi possível notar a misoginia com que o eu-lírico trata as personagens femininas, apresentadas nos poemas como figuras ambiciosas e estéreis. 
Estes poemas são traçados pela linha paródica, uma vez que visam à imitação e à crítica da vertente simbolista "sério-estética". O vocabulário, por sua vez, possui cunho mais literário do que popular, em vista de atender aos anseios do poeta de zombar ironicamente, tanto os simbolistas quanto o culto do astro estéril.

Já as construções em torno do Pierrô lunar, seguem o viés da interioridade, pois possuem um tom mais confessional, o que permite o aparecimento de monólogos interiores amargurados, repletos de spleen e niilismo. Perpassados por uma atmosfera mais decadente, estes poemas estão embasados do pessimismo e do negativismo de Schopenhauer e Hartmann, originando composições de cunho filosófico e existencial, discutindo questões inerentes à figura humana e a sua universalidade de sentimentos, sensações e decepções. As correntes filosóficas desses dois grandes nomes foram ao encontro do ennui do poeta, aproximando seus poemas do pessimismo e da melancolia, apesar de imersos na comicidade, buscando na dissonância a tentativa de fuga desse tédio. Para tanto, o vocabulário utilizado é mais popular, deixando um pouco de lado a preocupação com a métrica, as rimas ricas e a intertextualidade, a qual aparece somente quando necessário para ilustrar determinadas situações.

Apesar das diferenças existentes entre os dois conjuntos de poemas, não se pode negar que eles se assemelham quanto à inovação e à originalidade, pelo uso de características peculiares do poeta e pelo trabalho com uma linguagem própria, o que permite a Laforgue ter seu valor literário reconhecido.

Por último, vale ressaltar que a presença de todos estes recursos necessita, por parte de quem se aventura pelos versos laforguianos, de um trabalho investigativo minucioso de vocabulário e referências, além de um conhecimento enciclopédico, calcado na intenção de melhor compreender e interpretar os poemas do escritor. É importante, ainda, lembrar que todas as análises realizadas neste trabalho tiveram o intuito de apresentar um pouco desses 
recursos que fazem parte da poética de Laforgue. Sendo assim, sugerem apenas uma das possíveis direções a serem tomadas nos estudos visando a um mais profundo entendimento da escrita do poeta francês. Cabe aos que se encorajarem a trilhar estes caminhos escolher quais trilhas percorrerão e quais pistas seguirão rumo às considerações sobre a obra deste intrigante escritor: Jules Laforgue. 


\section{Bibliografia}

ALLEMANN, B. De l'ironie em tant que príncipe littéraire. In: Poétique. no 36, nov. 1978.

BALAKIAN, A. O Simbolismo. São Paulo: Perspectiva, 2000.

BARBOSA, J.A. As ilusões da modernidade. In: As ilusões da modernidade: notas sobre a historicidade da lírica moderna. São Paulo: Perspectiva, 1986.

BAUDELAIRE, C. Les Fleurs du Mal: Paris: Éditions Garnier Frères, 1959.

BAUDELAIRE, C. Oeuvres Complètes. Texte établi, présenté et annoté par Claude Pichois. Paris: Gallimard, 1975.

BERTRAND, J. - P. Petite mythologie portative.Vortex, $\mathrm{n}^{\circ}$ 2. Université de Liège, 1998. Disponível em <http: //www.orsini.net/Laforgue/vortex2/bertrand2.htm>. Acesso em: 21 jan. 2009.

BONVICINO, R. (Org. e Trad.). Jules Laforgue: Litanias da lua. São Paulo: Iluminuras, 1989.

BOSI, A. (Org.). Leitura de poesia. São Paulo: Ática, 1996.

O ser e o tempo da poesia. 5 ed. São Paulo: Cultrix, 1997.

BRADBURY, M. e McFARLANE, J. (Org.). Modernismo: guia geral 1890-1930. Trad. Denise Bottmann. São Paulo: companhia das Letras, 1989.

CAMPOS, A. Verso, reverso, controverso. São Paulo: Perspectiva, 1978.

CANDIDO, A. Na sala de aula: caderno de análise literária. 3 ed. São Paulo: Ática, 1989.

CANDIDO, A. O estudo analítico do poema. 5 ed. São Paulo: Humanitas, 2006. 
CASSIRER, E. Linguagem e mito. Trad. de J. Guinsburg e Miriam Schnnaiderman. 4 ed. São Paulo: Perspectiva, 2003. (Debates, 50).

CHEVALIER, J. E GHEERBRANT, A. Dicionário de símbolos. 9 ed. Rio de Janeiro: José Olympio, 1995.

COELHO, W. Jules Laforgue - o poeta estrangeiro. Disponível em: < http://www.subcultura.org/artigos/462/jules-laforgue-o-poeta-estrangeiro.html >. Acesso em 20 fev 2010.

COMPAGNON, A. La seconde main ou le travail de la citation. Paris: Seuil, 1979.

COMPAGNON, A. Os cinco paradoxos da modernidade. Belo Horizonte: UFMG, 2003.

DÉCAUDIN, M. (Org.). L'esprit nouveau dans touts ses états. Paris: Minard, 1986.

DUARTE, L. P. Ironia e Humor na Literatura. Belo Horizonte: Editora PUC Minas; São Paulo: Alameda, 2006.

DURANT, G. A imaginação simbólica. Trad.de Carlos Aboim de Brito. 6ª Ed. Lisboa: Edições 70, 1964 (Perspectivas do Homem, 45).

DURRY, M.J. Jules Laforgue. Paris: Pierre Seghers, 1971.

FAUSTINO, M. Desmoralização da rotina. In: Artesanato da Poesia. São Paulo: Cia das Letras, 2004.

FAUSTINO, M. Poesia Experiência. São Paulo: Perspectiva, 1977.

FAVRE, Y.A. Laforgue et l'art de la dissonance. In: Décaudin, M. (Org.). L'esprit nouveau dans tous ses états. Paris: Minard, 1986.

FIKER, R. Mito e Paródia: entre a narrativa e o argumento. Araraquara: FCL/Laboratório Editorial/UNESP; São Paulo: Cultura Acadêmica Editora, 2000 (Ciências Sociais, 2).

FRIEDRICH, H. A estrutura da lírica moderna. Trad. de Marise M. Curioni. São Paulo: Duas Cidades, 1991. 
GOMES, A. C. O Simbolismo. São Paulo: Ática, 1994.

GROJNOWSKI, D. Jules Laforgue:spectacle et oralité. Vortex, $\mathrm{n}^{\circ} 1$, Université de Liège, 1997. Disponível em http://www.orsini.net/laforgue. Acesso em 20 jul 2007.

GROJNOWSKI, D. Jules Laforgue et les usages du mythe. Vortex, $\mathrm{n}^{\circ}$ 2. Paris VII, 1998. Disponível em <http: //www.orsini.net/Laforgue/vortex2/grojno2.htm>. Acesso em: 21 jan. 2009.

GROJNOWSKI, D. Jules Laforgue et l' “originalité”. Genève: Baconnière, 1988.

HAMBURGER, M. A verdade da poesia: tensões na poesia modernista desde Baudelaire. Trad. de Alípio Correia de Franca Neto. São Paulo: Cosac Naif, 2007.

HIDDLESTON J. A. Laforgue et les épigraphes de Hamlet. Vortex, $\mathrm{n}^{\circ} 2$. Oxford, Exeter College, 1998. Disponível em <http: //www.orsini.net/Laforgue/vortex2/hiddle2.htm>. Acesso em: 21 jan. 2009.

HOLMES, A. Hamlet de Shakespeare au risqué de Laforgue. Vortex, n 2. Oxford, 1998. Disponível em <http: //www.orsini.net/Laforgue/vortex2/holmes2.htm>. Acesso em: 21 jan. 2009.

HUTCHEON, L. Teoria e Política da Ironia. Trad. Julio Jeha. Belo Horizonte: UFMG, 2000.

HUTCHEON, L.Uma teoria da paródia. Lisboa: Edições 70, 1985.

HUYSMANS, J.K. Às Avessas. Tradução e estudo crítico de José Paulo Paes. São Paulo: Companhia das Letras, 1987.

JAKOBSON, R. Linguística. Poética. Cinema. São Paulo : Perspectiva, 1970 (Debates, 22).

JOUANNY, R. Moeurs et stratégies littéraires de l'avant-siècle. In: L'esprit nouveau: dans tous ses états. Paris: Minard, 1986.

LAFORGUE, J. Les Complaintes et les premiers poèmes. Paris: Gallimard, 1979. 
LAFORGUE, J.L'imitation de Notre-Dame la Lune - Des Fleurs de bonne volonté. Paris: Gallimard, 1979.

LAFORGUE, J. Oeuvres complètes - Lettres II (1883 - 1887). Paris: Mercure de France, 1915.

LAFORGUE, J.Últimos poemas do pierrô lunar. Trad. de Luiz Carlos de Brito Rezende. Minas Gerais: Sette Letras, 1997.

LAGARDE, A. Et MICHARD, L. Collection littéraire Lagarde et Michard - le XIX ème siècle. Paris : Bordas, 1969.

LEFEBVE, M. J. Estrutura do discurso da poesia e da narrativa. Coimbra : Livraria Almedina, 1980.

MARTINO, P. Parnasse et Symbolisme. 11 ed. Paris, Armand Colin, 1925.

MELO NETO, J. C. de. Obra Completa. Rio de Janeiro, Nova Aguilar, 1994.

MOISÉS, M. O Simbolismo. 2 ed. São Paulo: Cultrix, 1967.(A Literatura Brasileira, 4).

MORETTO, F. (Org.). Caminhos do decadentismo francês. São Paulo: Edusp/Perspectiva, 1989.

Letras Francesas: estudos da literatura. São Paulo: Edunesp, 1994.

MUECKE, D. C. Analyses de l'ironie. In: Poétique. n. 36, nov. 1978.

MUECKE, D. C. Ironia e o irônico. São Paulo: Perspectiva, 1995 (Debates, 250).

NATHAN, M. Les complaintes - L'imitation de notre-dame la lune. Paris: Hachette, 1974.

ORSINI, M.D. Laforgue et le "genre complainte”. Disponível em: < http://www.orsini.net/laforgue/complaintes/articles/index.htm>. Acesso em 21 ago 2009. 
PAES, J. P. Para uma Pedagogia da Metáfora. In: Os perigos da poesia e outros ensaios. Rio de Janeiro: Topbooks, 1997.

PAZ, O. A outra voz. Trad. de Wladir Dupont. São Paulo: Siciliano, 1993.

PEREIRA, M. H. R. Estudos de História da Cultura Clássica. 7 ed. Lisboa: Fundação Calouste Gulkbenkian, 0000 (Cultura Grega, 1).

PESSOA, F. Obra em prosa. Rio de Janeiro: José Aguilar, 1974.

PEYRE, H. A Literatura Simbolista. São Paulo: Cultrix: USP, 1983.

POUND, E. Ironia, Laforgue e um Pouco de Sátira. In: A Arte da Poesia. São Paulo: Cultrix, 1976.

REZENDE, L. C. B. Últimos poemas do pierrô lunar. Rio de Janeiro: Sette Letras, 1997.

SAINT-GÉRAND, J.-Ph. Jules Laforgue: Les Complaintes "où Saint-Malo rime avec Sanglot et Bocks avec Coq". Élementes de mise en perspective grammatical et stylistique. Université Blaise Pascal, 2000. Disponível em <http:

//www.chass.utoronto.ca/epc/langueXIX/laforgue/etude.htm>. Acesso em: 09 ago. 2009.

SCEPI, H. Poétique de Jules Laforgue. Paris: PUF, 2000 (Colléction Ecriture).

SPERBER, D. e WILSON, D. Les ironies comme mentions. In: Poétique. n. 36, nov. 1978.

STRATHERN, P. Schopenhauer (1788-1860) em 90 minutos. Trad. de Maria Helena Geordane; consultoria Danilo Marcondes. Rio de Janeiro: Jorge Zahar, 1998.

TELES, G. M. A “Belle Époque”. In: Vanguarda européia e Modernismo brasileiro: apresentação dos principais poemas, manifestos, prefácios e conferências vanguardistas, de 1857 a 1972. 11 ed. Petrópolis, RJ: Vozes, 1992.

Tempo Brasileiro: Sobre a Paródia. n. 62, 1980.

URBANO, H. Oralidade na Literatura: o caso Rubem Fonseca. São Paulo: Cortez, 2000.

WEITZEL, A. H. Folclore Literário e Lingüístico: pesquisas de literatura oral e de linguagem popular. 2. ed. Juiz de Fora: EDUFJF, 2005. 
WILSON, E. O Simbolismo. In: O Castelo de Axel: estudo sobre a literatura imaginativa de 1870 a 1930. Trad. de José Paulo Paes. São Paulo: Cultrix, 1967.

ZACHARAKIS, G. E. Mitologia Grega: genealogia das suas dinastias. Campinas: Papirus, 1995. 


\section{Anexos}

Constam os poemas que foram citados nesta dissertação e aqueles dos quais foram analisados somente alguns versos.

\section{Petites misères de juillet}

(Le Serpent de l'Amour

Monte, vers Dieu, des linges.

Allons, rouges méninges, Faire un tour.)

Écoutez, mes enfants! - «Ah! mourir, mais me tordre «Dans l'orbe d'un exécutant de premier ordre! » Rêve la Terre, sous la vessie de saindoux De la Lune laissant fuir un air par trop doux, Vers les Zéniths de brasiers de la Voie Lactée (Autrement beaux ce soir que des Lois constatées)... Juillet a dégainé ! Touristes des beaux yeux, Quels jubés de bonheur échafaudent ces cieux, Semis de pollens d'étoiles, manne divine Qu'éparpille le Bon Pasteur à ses gallines !.... Et puis, le vent s'est tant surmené l'autre nuit ! Et demain est si loin ! et ça souffre aujourd'hui ! Ah! pourrir !.,. - Vois, la Lune-même (cette amie) Salive et larmoie en purulente ophtalmie....

Et voici que des bleus sous-bois ont miaulés Les milles nymphes! et (qu'est-ce que vous voulez) Aussitôt mille touristes des yeux las rôdent, Tremblants, mais le cœur harnaché d'âpres méthodes! Et l'on va. Et les uns connaissent des sentiers Qu'embaument de trois mois les fleurs d'abricotiers; Et les autres, des parcs où la petite flûte De l'oiseau bleu promet de si frêles rechutes (Oh! ces lunaires oiseaux bleus dont la chanson Lunaire, après dégel, vous donne le frisson !) Et d'autres, les terrasses pâles où le triste Cor des paons réveillés fait que Plus Rien n'existe ! Et d'autres, les joncs des mares où le sanglot Des rainettes vous tire maint sens mal éclos; Et d'autres, les prés brûlés où l'on rampe; et d'autres, La Boue où, semble-t-il, Tout ! avec nous se vautre !....

Les capitales échauffantes, même au frais

Des Grands Hôtels tendus de pâles cuirs gaufrés, Faussent. - Ah! mais ailleurs, aux grandes routes, Au coin d'un bois mal famé, rien n'est aux écoutes.... Et celles dont le cour gante six et demi, Et celles dont l'âme est gris-perle, en bons amis, 
Et d'un port panaché d'édénique opulence, '

Vous brûlent leurs vaisseaux mondains vers des Enfances!....

«Oh! t'enchanter un peu la muqueuse du cœur! » « Ah! Vas-y, je n'ai plus rien à perdre à cett' heur', «La Terre est en plein air et ma vie est gâchée,

«Ne songe qu'à la Nuit, je ne suis point fâchée. » Et la vie et la Nuit font patte de velours....

Se dépècent d'abord de grands quartiers d'amour.... Et lors, les chars de foin, pleins de bluets, dévalent Par les vallons des moissons équinoxiales....

Ô lointains balafrés de bleuâtres éclairs

De chaleur ! puis ils regrimperont, tous leurs nerfs

Tressés, vers l'hostie de la Lune syrupeuse....

- Hélas! tout ça, c'est des histoires de muqueuses.,...

- Détraqué, dites-vous? Ah! par rapport à Quoi?

- D'accord; mais le Spleen vient, qui dit que l'on déchoit

Hors des fidélités noblement circonscrites.

- Mais le Divin chez nous confond si bien les rites!

- Soit; mais le Spleen dit vrai : ô surplis des Pudeurs, C'est bien dans vos plis blancs tels quels qu'est le Bonheur !

- Mais, au nom de Tout! on ne peut pas! La Nature

Nous rue à dénouer dés Janvier leur ceinture !

- Bon! si le Spleen t'en dit, saccage universel!

Nos êtres vont par sexe, et sont trop usuels,

Saccagez! - Ah! saignons, tandis qu'elles déballent

Leurs serres de Beauté pétale par pétale!

Les vignes de nos nerfs bourdonnent d'alcools noirs,

Ô Sours, ensanglantons la Terre, ce pressoir

Sans Planteur de Justice! - Ah? tu m'aimes, je t'aime!

Que la Mort ne nous ait qu'IVRES-MORTS DE NOUS-MEMES

(Le Serpent de l'Amour

Cuve Dieu dans les linges;

Ah! du moins nos méninges

(Des Fleurs de bonne volonté, 1979, p.92)

\section{Petites misères d'octobre}

Octobre m'a toujours fiché dans la détresse;

Les Usines, cent goulots fumant vers les ciels....

Les poulardes s'engraissent Pour Noël.

Oh ! qu'alors, tout bramant vers d'albes atavismes, Je fonds mille Icebergs vers les septentrions

D'effarants mysticismes

Des Sions !....

Car les seins distingués se font toujours plus rares;

Le légitime est tout, mais à qui bon ma cour ? 
De qui bénir mes Lares

Pour toujours?

Je ferai mes oraisons aux Premières Neiges;

Et je crierai au Vent : «Et toi aussi, forçat !»

Et rien ne vous allège

Comme ça.

(Avec la Neige, tombe une miséricorde

D'agonie ; on a vu des gens aux cœurs de cuir

Et méritant la corde

S'en languir.)

Mais vrai, s'écarteler les lobes, jeu de dupe....

Rien, partout, des saisons et des arts et des dieux,

Ne vaut deux sous de jupe,

Deux sous d'yeux.

Donc, petite, deux sous de jupe en œillet tiède,

Et deux sous de regards, et tout ce qui s'ensuit....

Car il n'est qu'un remède

A l'ennui.

(Des Fleurs de bonne volonté, 1979, p.117)

\section{Petites misères d'hiver}

Vers les libellules

D'un crêpe si blanc des baisers

Qui frémissent de se poser,

Venus de si loin, sur leurs bouts cicatrisés,

Ces seins, déjà fondants, ondulent

D'un air somnambule...

Et cet air enlise

Dans le défoncé des divans

Rembourrés d'eiders dissolvants

Le Cygne du Saint-Graal, qui rame en avant !

Mais plus pâle qu'une banquise

Qu'Avril dépayse....

Puis, ça vous réclame,

Avec des moues d'enfant goulu,

Du romanesque à l'absolu,

Mille Pôles plus loin que tout ce qu'on a lu !....

Laissez, laissez le Cygne, ô Femme!

Qu'il glisse, qu'il rame,

Oh ! que, d'une haleine,

Il monte, séchant vos crachats,

Au Saint-Graal des blancs pachas,

Et n'en revienne qu'avec un plan de rachat 
Pour sa petite sœur humaine

Qui fait tant de peine....

(Des Fleurs de bonne volonté, 1979, p.124)

\section{Petites misères d'août}

Oh! quelle nuit d'étoiles, quelles saturnales!

$\mathrm{Oh}$ ! mais des galas inconnus

Dans les annales

Sidérales!

Bref, un Ciel absolument nul

Ô Loi du Rythme sans appel!

Que le moindre Astre certifie

Par son humble chorégraphie Mais nul spectateur éternel.

Ah! la Terre humanitaire

N'en est pas moins terre-à-terre!

Au contraire.

La Terre, elle est ronde

Comme un pot-au-feu,

C'est un bien pauv' monde

Dans l'Infini bleu.

Cinq sens seulement, cinq ressorts pour nos Essors..

Ah! ce n'est pas un sort!

Quand donc nos cœurs s'en iront-ils en huit-ressorts

Oh! le jour, quelle turne!

J'en suis tout taciturne.

Oh! ces nuits sur les toits!

Je finirai bien par y prendre froid.

Tiens, la Terre,

Va te faire

Trés-lan laire!

- Hé! pas choisi

D'y naître, et hommes!

Mais nous y sommes,

Tenons-nous y!

La pauvre Terre, elle est si bonne!....

Oh! désormais je m'y cramponne

De tous mes bonheurs d'autochtone.

Tu te pâmes, moi je me vautre.

Consolons-nous les uns les autres.

(Des Fleurs de bonne volonté, 1979, p.131) 


\section{Petites misères de mai}

On dit : l'Express

Pour Bénarès!

La Basilique

Des gens cosmiques !...

Allons, chantons

Le Grand Pardon!

Allons, Tityres

Des blancs martyres !

Chantons: Nenni !

A l'Infini,

Hors des clôtures

De la Nature !

(Nous louerons Dieu,

En temps et lieu.)

Oh ! les beaux arbres

En candélabres !....

Oh ! les refrains

Des Pèlerins !....

Oh! ces toquades

De Croisades !....

- Et puis, fourbu

Dès le début.

Et retour louche....

- Ah ! tu découches !

(Des Fleurs de bonne volonté, 1979, p.147)

\section{Petites misères d'automne}

HAMLET.Get thee to a nunnery : why wouldst thou be a breeder of sinners? I am myself indifferent honest; but yet I could accuse me of such things, that it were better my mother had not borne me. We are arrant knaves, all; believe none of us. Go thy ways to a nunnery.

Je me souviens, - dis, rêvé ce bal blanc?

Une, en robe rose et les joues en feu,

M'a tout ce soir-là dévoré des yeux,

Des yeux impérieux et puis dolents,

(Je vous demande un peu!) 
Car vrai, fort peu sur moi d'un en vedette,

Ah! pas plus ce soir-là d'ailleurs que d'autres, Peut-être un peu mon natif air d'apôtre, Empêcheur de danser en rond sur cette Scandaleuse planète.

Et, tout un soir, ces grands yeux envahis De moi! Moi, dos voûté sous l'A quoi Bon? Puis, partis, comme à jamais vagabonds! (Peut-être en ont-ils peu après failli ?...) Moi quitté le pays.

Chez nous, aux primes salves d'un sublime, Faut battre en retraite. C'est sans issue. Toi, pauvre, et t'escomptant déjà déçue Par ce cœur (qui même eût plaint ton estime) J'ai été en victime,

En victime après un joujou des nuits ! Ses boudoirs pluvieux rnirent en sang Mon inutile cœur d'adolescent...

Et j'en dormis. A l'aube je m'enfuis... Bien égal aujourd'hui.

(Des Fleurs de bonne volonté, 1979, p.149)

\section{Cas rédhibitoire (Mariage)}

Ah! mon âme a sept facultés! Plus autant qu'il est de chefs-d'œuvre, Plus mille microbes ratés Qui m'ont pris pour champ de manœuvre.

Oh! le suffrage universel

Qui se bouscule et se chicane,

À chaque instant, au moindre appel,

Dans mes mille occultes organes !....

J'aurais voulu vivre à grands traits, Le long d'un classique programme Et m'associant en un congrès Avec quelque classique femme.

Mais peut-il être question D'aller tirer des exemplaires De son individu si on N'en a pas une idée plus claire ?....

Arabesques de malheur Nous nous aimions comme deux fous; On s'est quittés sans en parler.

(Un spleen me tenait exilé

Et ce spleen me venait de tout.) 
Que ferons-nous, moi, de mon âme,

Elle de sa tendre jeunesse !

Ô vieillissante pécheresse,

Oh! que tu vas me rendre infâme!

Des ans vont passer là-dessus;

On durcira chacun pour soi;

Et plus d'une fois, je m'y vois,

On ragera : «Si j'avais su! »....

Oh! comme on fait claquer les portes,

Dans ce Grand Hôtel d'anonymes!

Touristes, couples légitimes,

Ma Destinée est demi-morte!....

- Ses yeux disaient : «Comprenez-vous!

«Comment ne comprenez-vous pas!»

Et nul n'a pu le premier pas;

On s'est séparés d'un air fou.

Si on ne tombe pas d'un même

Ensemble à genoux, c'est factice,

C'est du toc. Voilà la justice

Selon moi, voilà comment j'aime.

(Des Fleurs de bonne volonté, 1979, p.169) 